Article

\title{
Exploring Returnee Migrant Women, COVID-19 and Sustainability in Spain
}

\author{
Maria Luisa Di Martino
}

Citation: Di Martino, M.L. Exploring Returnee Migrant Women, COVID-19 and Sustainability in Spain. Sustainability 2021, 13, 9653. https:// doi.org/10.3390/su13179653

Academic Editors: Tehmina Khan and Pavithra Siriwardhane

Received: 3 July 2021

Accepted: 18 August 2021

Published: 27 August 2021

Publisher's Note: MDPI stays neutral with regard to jurisdictional claims in published maps and institutional affiliations.

Copyright: (C) 2021 by the author. Licensee MDPI, Basel, Switzerland. This article is an open access article distributed under the terms and conditions of the Creative Commons Attribution (CC BY) license (https:// creativecommons.org/licenses/by/ $4.0 /)$.
Department of Linguistics and Comparative Cultural Studies, Università Ca' Foscari Venezia, Dorsoduro 3199, 30123 Venice, Italy; marialuisa.dimartino@unive.it

\begin{abstract}
The COVID-19 pandemic has signified an historical change in human mobility. By transforming the patterns of people on the move, it has highlighted gender-based inequalities and women's vulnerabilities. The link between COVID-19 and return migration shapes returnees' readaptation process in their home countries, as returnees are embedded in a limbo between the pandemic's pressure on the policy and socio-economic setting, on one hand, and their efforts for reintegration, on the other. Due to the pandemic, the gender-based imbalance has increased existing gender gaps both in migration and return, exacerbating women's vulnerability. Thus, personal aspirations and professional expectations of highly educated women are caught in a system of socio-economic and geographical (im)mobility, which represents the principal outcome in their relocation and readaptation process. Based on a qualitative methodology through the analysis of ten life histories of highly educated returnee migrant women, this paper sheds light on the impacts of the COVID-19 pandemic on their migratory trajectories, providing a typology of them. Findings stress the necessity for more sustainable measures and resources for life-work balance and gender-sensitive policies, to promote a better integration process into the local labour market; to mitigate the effects of COVID-19 on returnee women, and to prevent the proliferation of mental health problems among returnee women.
\end{abstract}

Keywords: sustainability; gender; sustainable human mobility; inclusion; return migration; COVID-19

\section{Introduction}

This paper is based on two previous studies: (a) the first one is focused on the sociooccupational integration of highly educated migrant women from different nationalities in Spain, carried out between 2015 and 2019, during my PhD thesis and published in "Migration at Work: Aspirations, Imaginaries and Structures of Mobility" [1]; (b) the other is focused on the experience of return migration of Spanish Self-Initiated Expatriates (SIE) women, with high levels of education, during and after the COVID-19 pandemic and published in the framework of the Spanish RDI project addressed to Social Challenges: "Instrumentación Normativa de la Política de Retorno de Emigrantes Españoles y la Atracción de Talento Global" (RTI2018-099274-B-I00) which is about the Spanish policies and rules of return of talents, carried out by the University of Granada (Spain) [2]. The findings of both studies show that women respondents' migratory trajectories and professional careers are strongly influenced by the articulation of macro, meso and micro dimensional elements and a structure of opportunities and constrains, which foster or hinder migrant women or SIE women returnee's (re)integration process [1,2]. My hypothesis is that the socio-economic and professional reintegration and readaptation process of Spanish SIE women with a high educational level returned to their home country (Spain), due to COVID-19 complications, is similar to the integration process of highly educated migrant women from different nationalities in Spain as their host country. Thus, it would mean that both migrant women and returnee women share the same dynamics during the process of socio-professional integration and adaptation within the framework of human mobility and the pandemic could turn mobility into long-term immobility. 
Scholars have traditionally approached the emigration and return migration phenomena as two different socio-economic dynamics within the framework of migration studies. Such a separation is reflected in public policies, the management of return migration, and the imaginaries and discourses on emigration and return flows, influencing returnees' trajectories and their decision-making processes. Nevertheless, returnees' imaginaries seem to be different from the reality they have to face in the home country, involving dissatisfaction and readaptation problems, which they have to deal with [3].

According to the International Organization for Migration (IOM), return migration is conceptualized on the basis of two definitions: (a) voluntary return; and (b) forced return. In this paper, I refer to return migration, making a claim for a reconceptualization of the definitions of return migration based on the relationship between human mobility and sustainability in the COVID-19 pandemic setting, in which voluntary and forced decisions were mixed during a global emergency, drawing large restrictions and policy responses. I address the issue of highly educated Spanish women, who were in a SelfInitiated-Expatriation (SIE) situation and decided to come back home before and during the pandemic, in order to explore the impacts of COVID-19 on their migratory trajectories in the context of return migration, considering that their (re)integration process has similarities with the migratory careers of highly educated migrant women of different origins settled in Spain. Thus, on the one hand, I approach the return migration of Spanish SIE women in the framework of human mobility, "defined as people's capability to choose where to live" [4]. On the other hand, I explore the Spanish SIE women's voluntary or involuntary decisions for resettlement in their home country due to the complications of the COVID-19 pandemic. These issues should be addressed in order to solve the dilemma of socioeconomic (im)mobility and sustainability in highly educated women returnees' experience of return migration.

According to the Global Combat for Migration (GCM), we are witnessing a "growing global understanding of the great benefits of human mobility" [5]; at the same time, they recognize that migration generates challenges, risks, rights vulnerability and social tensions [6], showing "the need for better planning, facilitating and funding to manage return, reception and reintegration" (p. 7) after the COVID-19 shock. During the COVID-19 pandemic, those challenges have been heightened and COVID-19 has had negative effects on more than 2.7 million migrants' socio-economic situation, as reflected in the loss of jobs, involuntary replacements due to unemployment and difficulties in life-work balance, particularly for women and girls [7,8]; in the latter case, gender-based violence increased during the pandemic and lockdown, according to data confirmed in the Basque Country by the Institute for the Women, Emakunde [9].

Data from the INE at Spanish level are reflected the United Nations data on the declining situation of women in the labour market, at international level, which show a decline in the situation of women in the labour market [10]. Therefore, the socio-economic situation of women returnee migrants to Spain experienced a more difficult impasse during COVID-19. The pandemic setting added an additional burden to reintegration and readaptation problems, placing women returnees in a more vulnerable position in societies, facing decreased access to reproductive and maternal health care and economic opportunities [11]. In this context of global crisis, the question of sustainability is mandatory. The latest studies show that in Europe the situation of vulnerable groups during the COVID19 pandemic has worsened [12]. Therefore, "people who were marginalized before the coronavirus were disproportionately impacted by the situation". COVID-19 has made visible previously invisible realities embedded in gender gaps and "exacerbating existing inequalities" [13]. Related to this, sustainability is a core question in the context of recovery. Hence, countries have implemented different socio-economic measures and actions for protecting migrant populations. However, what are the emerging positive practices in the case of returnee migrants and returnee women? Return migration is a complex process with challenges and opportunities, affecting each subject differently, [4] and has to face barriers to successful incorporation into migration policies and practices. How do returnee women 
manage their return? How does Spain manage return migration effectively? Support in the reintegration process ensures sustainability of return without creating pull factors and/or incentives for irregular migration and return migration.

According to Silvia Marcu, "the concept of sustainability gains relevance and contributes to the creation of new models of mobility in the time of pandemic" [11] (p. 1). Understanding what is happening to returnee women, and how they are responding to their needs of inclusion, can help rebuild stronger, more effective public policies and protection systems for a more sustainable reintegration process. Sustainability in return migration to the country of origin of SIE women is linked not only to the agency of returnees, but also to support actions of governments and international organizations involved in the fight against COVID-19.

On the one hand, from a gender perspective, this paper engages with GMC and the UN Women's strategy for confronting COVID-19 in women and girls. Therefore, it is linked to sustainability actions for the defence of human rights in a still vulnerable population. On the other hand, it is also important to stress the limitations of this study, which can be identified with the lack existing in literature and data on the link between the COVID-19 pandemic and socio-economic crisis; or the impacts of the pandemic on the reincorporation of returnee women in the labour market of their home country; and, finally, the scarce information on the link between COVID-19, human mobility and sustainability. Therefore, this study is situated in the field of human mobility and sustainability in the COVID-19 era, with the claims of authors such as Silvia Marcu in Spain [11]. Firstly, this article engages with the GMC, in particular with Objective 21 [5]: "Cooperate in facilitating safe and dignified return and readmission, as well as sustainable reintegration". To what extent do the COVID-19 responses address the special needs and vulnerabilities of expatriate and returnee women? Do measures for their empowerment exist? Secondly, it engages with the Beijing Declaration as an innovative way to address the issue, in order to establish key points for generating new knowledge and innovative future lines of research in different fields. The Beijing Declaration is based on the advancement of women and girls' health, inclusion and gender equality [14].

In the context of COVID-19, shaped by the pressure of the economic recession, difficulties in policy management and collapsed health systems, the GCM has seen the heaviest stage of this contemporary human mobility condition. In fact, due to COVID-19, migrants around the world, from international students to temporary and other workers and refugees, have lived through a precarious situation; because of travel restrictions, their families have experienced longer periods of involuntary immobility than ever, or have been left stranded without jobs and assistance in host countries. With regard to human mobility and the circulation of highly educated professionals, female migratory paths, both of emigration and return migration, as well as their patterns of (im)mobilities, are undertheorized [15,16]. Moreover, the studies on returnees' situation from a gender perspective, before and after the COVID-19 pandemic, have still been given little consideration in the research literature on migration [2].

This study aims to explore the life histories of ten highly educated Spanish SIE women, who experienced the unavoidable impacts of COVID-19 in their socio-occupational reintegration and readaptation processes in their return to Spain, with an emphasis on their socio-occupational situation. The main aim is to show which fostering and hindering factors are influencing the readaptation and reintegration process of SIE returnee women in different geographical areas of Spain, and the main strategies applied for bypassing discomforts and dissatisfaction problems, in the COVID-19 pandemic context. Thus, the questions I want to address with this work are the following: How does the COVID-19 crisis affect returnee women and their mobility process in Spain? Which are the structures of power/oppression and the hindering/fostering factors influencing returnee women's reintegration processes in Spain during COVID-19, based on the intersection of macro, meso and micro dimensionality? This paper, thus, provides new insights on the experience of the return of SIE women to their country of origin (which is Spain). For that purpose, 
I use the life history as a qualitative research method, and I develop the (re)construction of their migratory careers from the life-course perspective. Life history is the most appropriate method for exploring life cycles [17] in human mobility research and its link with sustainability. In addition, I use the "migratory career" [18] multidimensional lens, which allows me to explore the subjects' micro-historical (individual) experiences within a macrohistorical (history of the time) framework, as well as the returnee women's migratory trajectories, networks and relationships, and occupational (im)mobility.

By using the case study of Spanish returnee women to different geographical areas of Spain, this contribution to the scientific knowledge on Self-Initiated Expatriate and returnee women is focused on how the COVID-19 crisis has affected women's mobility and the sustainability of their return process to the country of origin. As the analysis of returnee women's biographies is suitable for addressing their little-known needs, a brief summary of the literature related to such women's profile will be presented in the corresponding section below. Findings and results will be given though the illustration of returners' interviews and the creation of a typology of returnee women's trajectories and behaviours, influenced by the COVID-19 pandemic setting.

Finally, the present paper is structured as follows: firstly, it introduces the link between emigration, return migration, human mobility and sustainability in the COVID-19 setting in the Spanish context from a gender perspective. Secondly, it explains a brief theoretical framework which connects human mobility and sustainable reintegration processes of highly educated returnee women. Thirdly, the present paper introduces the methodological strategy. After that is the analysis of the respondents' life histories, carried out through a multidimensional approach, and the discussion of results presented follows. Finally, in the conclusion the paper emphasizes suggestions for future research guidelines and new landscapes on the problematic around sustainability and women's mobility in a context of return migration.

\subsection{The Spanish Context of Immigration, Emigration and Return Migration}

According to the most recent data of the Spanish National Institute of Statistics (INE), in Spain there are 6.104 .203 immigrants, corresponding to the $12.9 \%$ of population, in a constant growth for the past two decades (Figure 1) [19].

The principal nationalities of migrant population in Spain are Colombian $(35,112)$, Moroccan $(21,930)$ and Venezuelan $(20,273)$. In 2020 there were 2,714,276 migrant women and 2,719,877 migrant men in Spain, which indicates the existence of a gender balance in the migration flow in 2020, according INE data [19] and confirms the feminization of migrations in Spain, linked to the socio-economic and demographical needs of the Spanish society, feeding the reproduction of the global care chain [20,21]. According to the data of the Survey on Migrant Women in Spain, carried out by IOM and the Instituto Universitario de Estudios sobre Migraciones of the University of Comillas [22], migrant women in Spain are $14 \%$ of the population, their profile is mostly from Latin-American countries (51\%) and they are employed in domestic work and the care and services sectors (approximately the $90 \%$ ). Migrant women with university degrees are $28 \%$ and $2.4 \%$ are low skilled. In addition, they suffer from the gender division of labour, in which women respond to the private sphere of the economy, the care and domestic work. In that sense, it may be stressed that labour mobility also responds to different regimes of mobility and geographical and temporal positioning. 


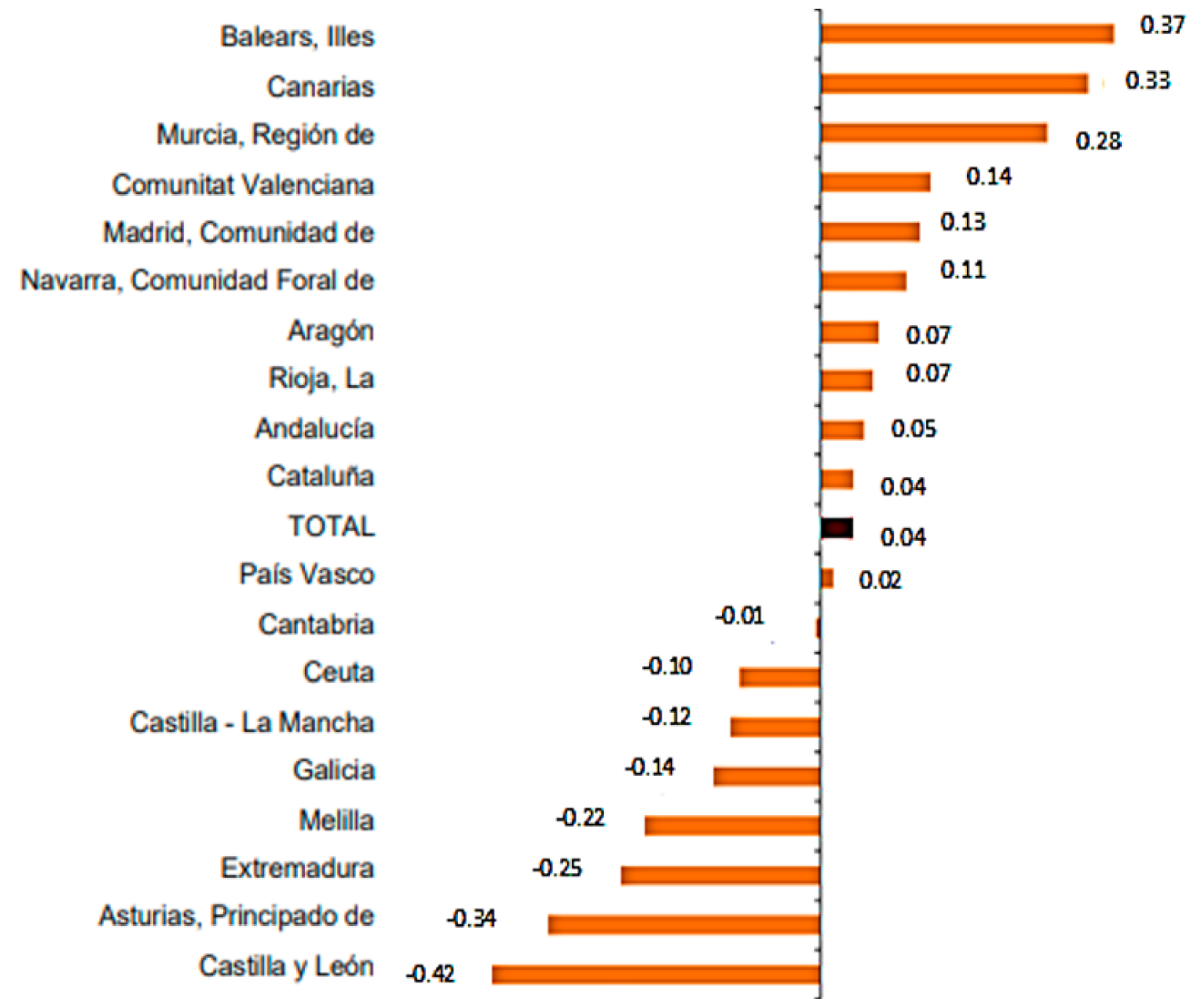

Figure 1. Immigration rate in the Spanish Autonomous Communities. Source: INE, 2020.

The gender composition of contemporary migrant flows is linked to the rise of a stronger demand for female labour in the private sphere of the economic system. As Donato and Gabaccia [23] claim, the gender imbalance in migration is directly linked to the structure of opportunities and constraints dictated by coercive systems and specific public policies, contributing to selected standards and criteria based on the needs of local labour markets. If it is clear that this approach in migration and human mobility studies has revealed vulnerabilities and unsolved problems with the socio-economic integration process of migrant women in Spain as a host country, my claim is the urgency to investigate the situation of returnees, and in particular of SIE women returned voluntarily or involuntarily due to the pandemic, and the urgency to study their trajectories situated in the COVID-19 landscape, in order to be aware and prepared to prevent and/or mitigate the possible and potential risks and negative impacts of the COVID-19 pandemic on migrant women, SIE and their families in the context of human mobility, included in the return migration situation due to SARS-CoV-2, as it is little investigated [2]. Thus, understanding the causes and consequences of differing migration and mobility patterns among men and women, and the different impacts on their personal and professional trajectories, requires a delimitation of concepts to be carried out. In this case, I centred attention on women, because they are the more vulnerable group in migration studies, based on the evidence in the existing literature [1,11,22-24].

On the other hand, emigration is a new phenomenon in Spain, increasing since 2007 and corresponding with the last economic and financial crisis, which have seen a high number of young people engage in emigration and Self-Initiated Expatriation, in order to find better job opportunities abroad (Figure 2) [25].

Related to women's emigration, existing data on Spanish human mobility show that the number of Spanish women who have emigrated in the last ten years is superior to the number of men [26] (Table 1). 


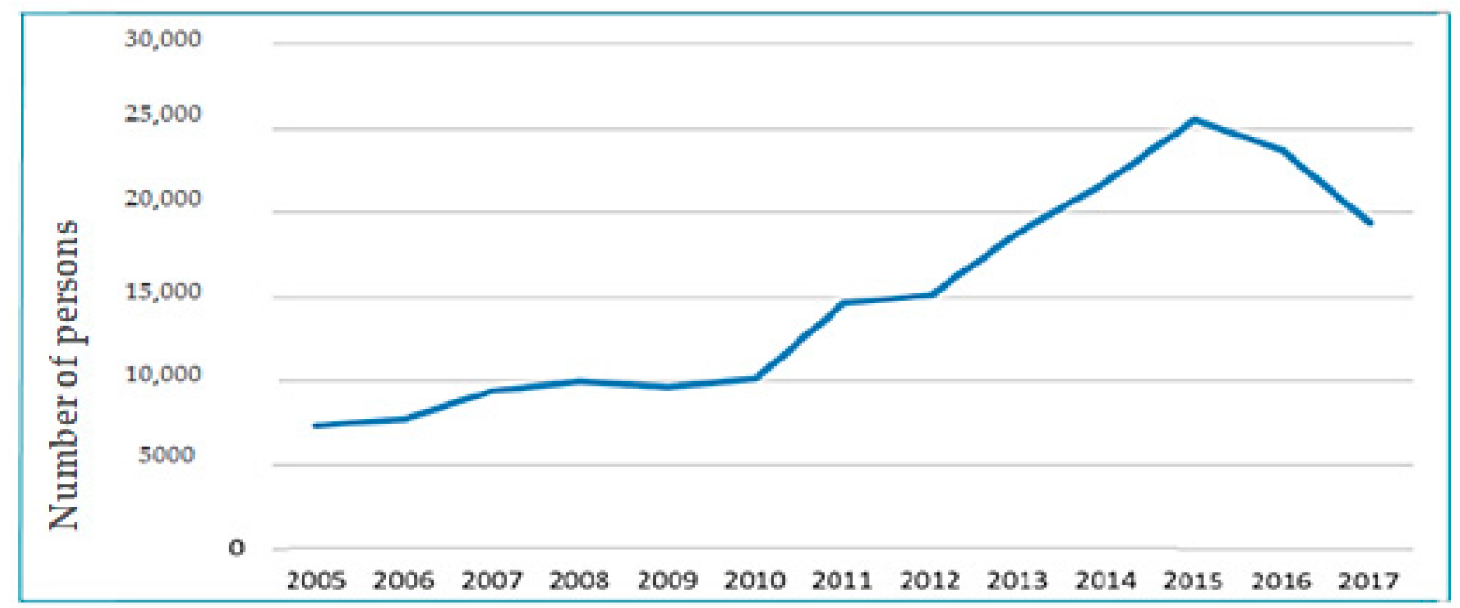

Figure 2. Emigration of young people (25-34 years-old), Spain (2005-2017).

Table 1. Evolution of Spanish emigration rates (1990-2019).

\begin{tabular}{ccccc}
\hline Year & Men & Women & Total & $\%$ \\
\hline 2019 & 666.443 & 778.499 & 1444.942 & $3.05 \%$ \\
\hline 2017 & 609.615 & 736.247 & 1345.862 & $2.88 \%$ \\
\hline 2015 & 579.112 & 691.908 & 1271.020 & $2.74 \%$ \\
\hline 2010 & 489.494 & 597.058 & 1086.552 & $2.33 \%$ \\
\hline 2005 & 510.206 & 603.761 & 1113.967 & $2.53 \%$ \\
\hline 2000 & 588.290 & 701.989 & 1290.279 & $3.17 \%$ \\
\hline 1995 & 635.429 & 727.010 & 1362.439 & $3.42 \%$ \\
\hline 1990 & 683.813 & 755.206 & 1439.019 & $3.70 \%$ \\
\hline
\end{tabular}

Data in Table 1 are focused on the evolution of Spanish emigration approached from a gender perspective. Source: "Economía de España", 2020.

By contrast, as the latest data of INE [27] show, the population with Spanish nationality who returned to Spain is a quite new phenomenon, which has increased exponentially in recent years. A complete qualitative data perspective of return related to the COVID-19 period is not yet available, but during the last year the rate has risen (Figure 3). Nevertheless, qualitative data on the situation of emigration and return in Spain are still scarce.

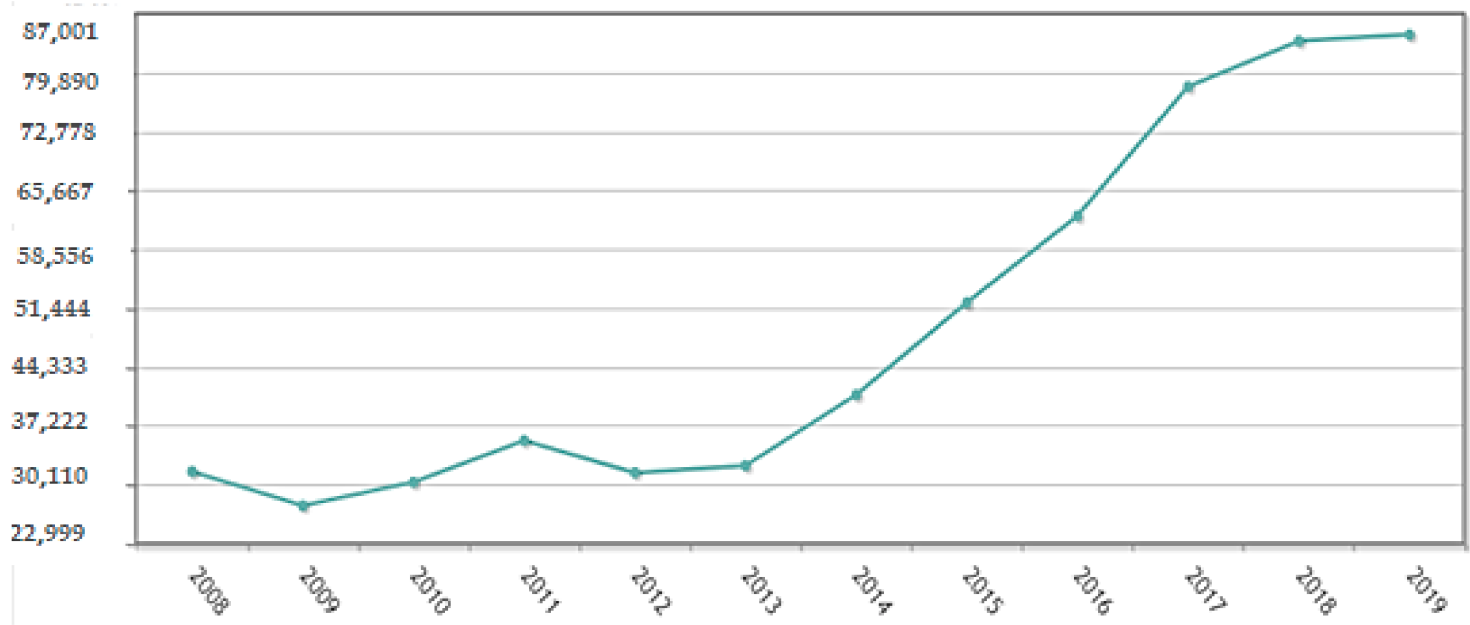

Figure 3. Return of Spanish population to Spain. Source: INE, 2020. 


\subsection{Return in the Context of the COVID-19 Pandemic}

Human mobility and COVID-19 are turning into discourses of immobility. If, on the one hand, migrants are the most affected by the pandemic situation and its economic effects in destination countries, on the other hand, the impact on socio-economic integration and the construction of opportunities is a big challenge in the case of returnees in pandemic times. During the COVID-19 period, in fact, when migrants returned home, countries of origin and local authorities provided for the wide range of returning migrants' needs: access to safe and child-friendly quarantine and basic services, securing decent work and social protection, and protecting against stigma and discrimination. There are concerns that millions of migrant workers will be forced to return home due to lack of employment and social protection, only to face labour markets in their home countries that are under considerable strain with high levels of unemployment due to the pandemic. In some countries, at global level, the "lack of bilateral cooperation can hinder economic support to migrants who have lost their jobs and reduce migrants' preparation for re-entry and reintegration into labour markets in their home countries" [28]. According to Objective 21 of the GCM [5], on which this paper is based, currently "as migrants voluntarily return to their home countries, all actors must cooperate to ensure such returns are safe, dignified and voluntary and that reintegration is sustainable. Governments must ensure that nationals who wish to return home voluntarily are duly received and readmitted, in full respect for the human right to return to one's own country and the obligation of States to readmit their own nationals. "Voluntarily returning migrants must be included in national response, social protection and recovery strategies without discrimination, and protected against stigma and exclusion" [29] (p. 14). The same discourse should be applied to returnees; in the case of returnee women the situation presents more weaknesses, due to the multiple charges and responsibilities in family caring, work-life balance and increased workload.

\subsection{Self-Initiated Expatriates and Return Migration from a Gender Perspective}

Research on 'skilled' and 'highly skilled' migration has raised important questions about transnational migrant professionals and the relation between human and labour mobility. Starting from this group of professionals as transnational elites [30], in the extended literature on labour migration different approaches can be observed, based on the level of education, the job-education matching situation, transnational perspective and circulation of talented migrant people [31]. Thus, theories saw the evolution of highly skilled and highly wanted professionals [32] on the wave of needs established from the destination countries through skill-based migration programmes [33,34]. In this group, SIE's mobility is considered on the basis of self-election of highly educated professionals, whose mobility is also boosted by companies, the global labour market as a centre of opportunities and professional development [34]. On the other hand, in the literature on skilled or highly skilled migration there is a clear separation between low skilled/highly skilled (or low levels of education/high levels of educated) migrants in a world where markets and companies have dictated the rules on which the definitions and the standards for the attraction and selection of international professionals are based [35]. Thus, highly educated migrant professionals more often are categorized and represented as privileged in the migration literature [36-38]. Nevertheless, the position of women in human mobility shifts from privileged to vulnerable when human mobility crosses with gender, race, class and other categories and socio-cultural constructions, according to the theoretical and methodological approach given by situated intersectionality $[39,40]$.

Motivations for emigration and return among women are also an underexplored issue, as well as the consequences of mobility in returnee women's lives. In academic research, discourses on migration from a gender perspective has increased since the 1980s, through different studies showing the different structures and relations of power and oppression existing in the imaginaries and patterns of male and female migrants. Scholars show that different push/pull factors and different impacts, based on a gender perspective, affect the decisions of men and women in different way in human mobility. Thus, 
multiple discriminations in the feminised process of migration and human mobility and their high vulnerability in socio-occupational integration have been made visible. In Western countries, and European countries, the feminisation of migration and mobility is especially linked to structural needs, due to the demographic issues of an aging population and low level of birth rates. Such structural needs, thus, have drawn a polarised demand in the labour market: the low skilled/educated and the highly skilled/educated professionals [41]. In consequence, this dual separation between low and high levels of education/occupation sectors in the European labour market reflect directly the gendered labour market duality, based on the low sector occupied by low/highly skilled/educated migrant women, corresponding to the care sector and domestic work, on the one hand, and the highly skilled/educated for male dominant sectors, such as business, finance, ICT, STEMs, on the other hand. The labour market is based on a traditional gendered separation. By analysing human mobility from a gender perspective, it is stressed that different structures of power/oppression cross women, hindering their professional development, personal aspirations and family expectations, in the context of emigration, immigration, remigration or return. In the case of highly educated professionals, their expectations and aspirations do not always correspond to the reality of the labour market in the context of human mobility in which there are embedded [2]. Thus, these findings suggest that in the case of returnee women the same structures of power/oppression work together and influence their personal and professional paths, creating overqualification [42] and temporary or permanent deskilling [41,42], which require new strategies, measures and policies to transform their precarious condition of and vulnerability.

Ultimately, the main challenge in the human mobility framework is to overcome the dichromic thinking between the macro-analytical and micro-analytical dimensions of mobility, and to find the way to facilitate the synthesis of both. On the other hand, following de Haas: "agency reflects the (...) ability of human beings (...) to make independent choices and to impose these on the world and, hence, to alter the structures that shape and constrain people's opportunities or freedoms" [4] (p. 14). On the other hand, the structure is constituted by "factors and institutions such as class, religion, gender, ethnicity, networks and markets as well as cultural belief systems all sustain inequalities and social hierarchies and limit the opportunities that people have-or perceive they have-and the economic, social and cultural resources which they can access-thus significantly constraining their freedom or agency as well as their ideas, knowledge and self-consciousness" [4] (p. 14).

\subsection{Skills, Women in Mobilities and Sustainability}

A difficult conceptualization of skills in the literature should be stressed when human mobility scholars approach the issue of the lower/higher educational levels in professionals on the move. In fact, there is no common description of skills; thus, some scholars recognize the concept as a social construction, joining together different ontological issues such as qualification and occupational sector belonging, and functions in the description of work. In recent literature, skills are disengaged from the inner capabilities of individuals. It is stressed that skills are not an intrinsic quality of a person, but they can change, according to personal aspirations, desires and expectations, or depending on the concrete socio-cultural and economic context or labour market, and the local or global crisis situations [43,44], as the COVID-19 pandemic has shown. Thus, the concepts of skills, skilled or highly skilled professionals is used with high elasticity, which confirms that it is subjected to space and time or socio-cultural needs, changing in cross-border labour mobilities [44].

In my research I take as a point of departure the notion that 'skill' in cross-border labour mobility, and consequently the idea of the high- or low-skilled professionals on the move, is a "concept socially constructed by a constellation of actors in specific local, national, transnational and global contexts" [44] (p. 2240). It is not intrinsically correlated with educational level or occupational category. According to Nowicka [45] (p. 171), skills are not a fixed attribute, but change according to the socio-geographical and historical context, and also depend on "migration regimes, professional regulations and national policies". 
Empirical studies show that migrant women are able to acquire different skills during their mobility process, linked to their own empowerment and professional development; nevertheless, the labour situation in the country of origin may not be the same they left before emigrating. Thus, the relationship between skill and mobility is much more complex, because mobility is impelled by other inner and external logics, different from economic ones, in migrant women and returnee women's lives, and they have to be "negotiated within multiple life domains" [46] (p. 684). In the context of return, skills and phenomena linked to highly educated women returnees and their reintegration process into the labour market is a key issue directly linked with decent work conditions, human rights and sustainability. In that sense, their performances are similar to migrant women's experiences. As Liu-Ferrer et al. [47] show, "foreign graduates either fail to enter the market, or are placed in lower or niche categories in a differentiated labour market" (p. 2305).

\section{Theoretical Framework: Human Mobility and Sustainability from a Gender Perspective}

Migratory flows are getting more and more complex, as human mobility has increased, motivated by different often overlapping factors. In 2019 there were 272 million international migrants, which means $3.5 \%$ of the global population. Among them, $52 \%$ were men and $48 \%$ women; moreover, $74 \%$ of the international migrant population is of working age, between 20 and 64 years old (Figure 4) [7].

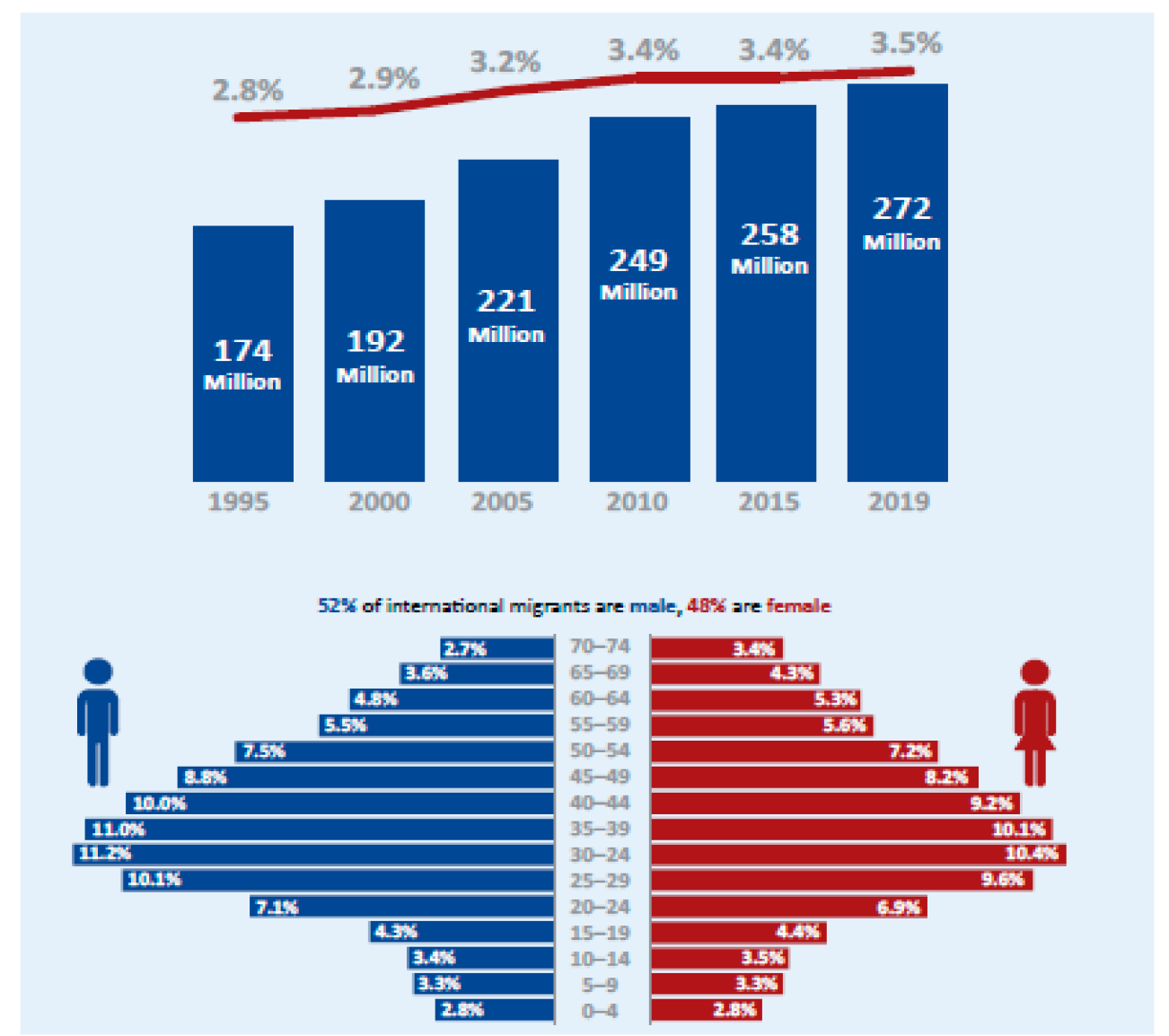

Figure 4. Snapshot of international migrants' data disaggregated by sex, showing the historical evolution of the phenomena. Source: IOM's World Migration Report, 2020 (p. 22).

The biggest group of migrants moves for economic reasons: $74 \%$ of international migrants were working-age people (from 20 to 64 years old), according to the last report of the IOM [7]. Human mobility is also linked to labour mobility and its forms of responding to the change in the labour-market situation with volatile rules, if analysed from a macro- 
perspective. Nevertheless, the most recent studies on migration and mobility from a human-centred approach, based also on the micro-analytical level of psychosocial factors and individual vectors of well-being, have shown the importance of other concerns among people on the move and their (im)mobility patterns, which are linked to sentimental reasons, aspirational motivations, and constructed imaginaries in their changing trajectories. As Silvia Marcu claims: "the spread of COVID-19 and its worldwide presence (...) has starkly exposed some of the limits and risks of human hypermobility" [11] (p. 2); thus, the pandemic exposed human mobility to a structural change during COVID-19, through the measures applied and restrictions imposed by governments all over the world to protect populations at the height of the global pandemic, transforming mobility into immobility patterns; affecting people on the move; and making them more vulnerable and marginalized than ever. "Migrants have been discriminated against and excluded from access to rights that are critical for effectively combatting the pandemic, including information, testing, health care, education, decent work, social protection, food, housing and other services" [48].

The COVID-19 pandemic has revealed critical deficiencies in access to decent work, as well as the devastating consequences of gaps in social protection coverage, unfair recruitment practices, and unsafe working conditions. Today's pandemic reality belongs to all people on the move: privileged migrants, vulnerable migrant groups and returnees [49]. From the human mobility approach the phenomenon of return migration is considered within a wider and global phenomenon of the circulation of human beings through even more porous boundaries in times of globalization, in which moving, staying and returning to the home country are "seen as complementary manifestation of migratory agency" [4] (p. 31). Nevertheless, the macro and micro factors influencing people's (im)mobility are combined to achieve a deeper understanding of the migration phenomenon and the social change. Therefore, it should be stressed that from a human-centred approach, migrant people get involved in several complex spatial and socio-cultural processes, in which they are key actors in activating complex movements, cross-cultural transitions and identity transformation processes [2]. It is noteworthy that the COVID-19 pandemic sheds light on the high impact of macro determinants which influence the principle of the voluntary in human mobility, especially in more vulnerable groups such as migrant or SIE women. Hence, the non-lineal relationship between macro, meso and micro determinants of human mobility push us to reconceptualise migrant women and returnees' aspirations, capabilities or skills and opportunities to migrate within structures of opportunities and constraints in a geographical setting [2].

Migrants are agents of social change [4] and their mobility and integration processes are extremely linked to the macro-level of structural dynamics, socio-political and sociocultural management in different local contexts. The COVID-19 pandemic has modified life and mobility all over the world, migrants' behaviours and migrants' perceptions on human mobility. Therefore, focusing on human mobility from a transversal gender perspective is a relevant concern, in order better to understand the heterogeneity of human mobility, as well as the dichotomy of mobility/immobility patterns and other re-integration processes in less investigated phenomena, such as the return of SIE women. A disadvantage in the return migration context for people on the move is related to long-term support measures and not short-term measures for socio-economic and occupational reintegration paths. Thus, the return migration phenomenon tests the capacity of governments of reintegration and social inclusion of returnees, as well as the resilience of families, communities and societies. In the existing literature on migrant people's return migration to the home country, there are not many positive examples of successful support measures for reintegration of returnees, and less about long-term reintegration policies and measures, due to the lack of efficient structures for the reintegration process addressed to respond returnees' real needs in the country of origin, as the IOM claims. In the research on migration and mobility, as can be noticed in the following graphics (Figure 5) - in which a reproduction of research themes downloaded in IOM's website and platforms on the issues linked to migrations and 
mobility is provided [8] — migration and return are not very popular among downloaded issues and problematics.

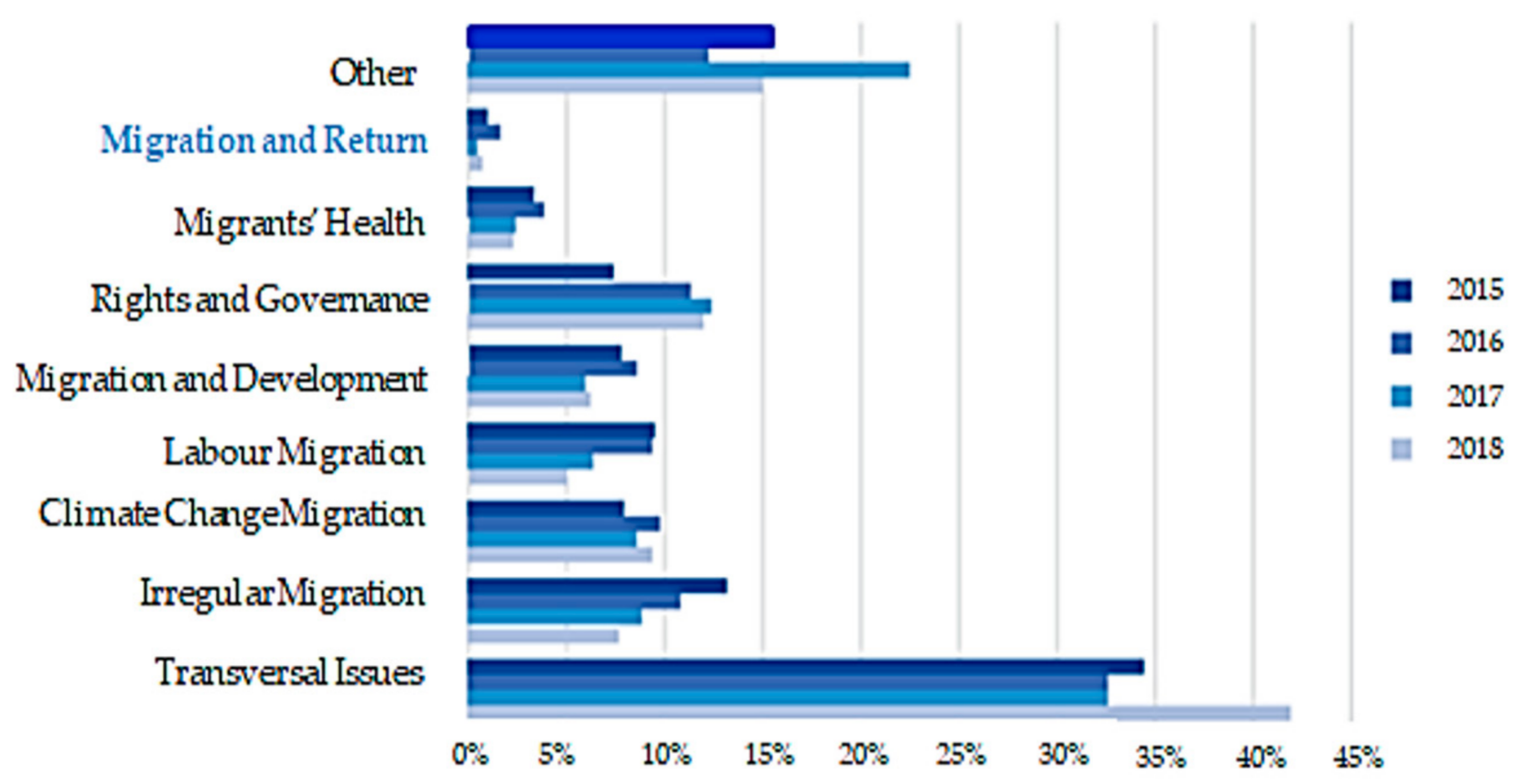

Figure 5. Proportion of downloading publications on IOM website, according to themes/years. Source: United Nations, Department for Economic and Social Affairs (UNDESA), Population Division, United Nations, 2019.

Moreover, from data on emigration and return migration, it can be noticed that, in relation to the return of citizens living abroad to their countries of origin, many governments report having policies or programmes to encourage return flows. In the IOM's report it is stressed that in $2019,33 \%$ of Governments reported having policies to raise levels of return of citizens living abroad, compared to $1 \%$ with policies to lower such flows (Figure 6). Sub-Saharan Africa had the highest proportion of governments reporting policies or programmes to raise the level of return of their citizens living abroad (42\%), followed by Central and Southern Asia (40\%), and Europe and North America (39\%). Policies to influence levels of return of international migrants to their country of origin are somewhat less prevalent; $23 \%$ of governments reported having policies to raise the level of migrant returns, while $25 \%$ sought to maintain current levels. Eastern and South-Eastern Asia had the highest proportion of governments with policies to raise migrant returns above current levels (43\%), followed by Europe and North America (32\%) [8].

Thus, among the studies conducted from a gender perspective in different areas of the globe, González et al. [50] focused their attention on the challenges and strategies of post-COVID-19 in sustainable mobility. Another study on perception and preference for home-based telework in the COVID-19 period from a gender-based analysis in Hanoi (Vietnam) was developed by Nguyen and Armoogum [51] and shows that women have more preference for teleworking then men. In addition, work-related factors are associated with the male perception, while family-related factors influenced the female perception. The urgency for solutions for women to mitigate overload due to mixed factors such as caring, parenting and teleworking is part of the suggestion for governments. Moreover, the psychosocial factors influencing the adoption of COVID-19 preventive behaviours, linked to pandemic risks and fears and analysed from a gender perspective, were explored by Bronfman et al. [52]. In their study results confirm significant gender-based differences for both the psychosocial factors and the adoption of preventive behaviours. Related to that, women show a higher level of worry and fear of the pandemic and are keener to adopt preventive hygiene and social distancing behaviours. Women also report the lowest trust 
levels in government authorities. By contrast, Irene Campos [53] analysed the variations that have existed in terms of female representation in the Spanish listed companies during the COVID-19 scenario. Her findings reveal that: (1) there has been a slight increase in the figures of female representation in different hierarchical positions; (2) the proportion of women on the boards of directors does not depend on the number of women in lower positions; and (3) there is a positive relationship between female representation in leadership positions and the number of women in the total workforce. Moreover, related to the gender perspective in the career progression dimension, it is also worth underscoring the recent study on the impact of COVID-19 on the prevalence of organisational factors at institutional level that represent relevant barriers to the professional evolution of women in the higher education sector in Australia, carried out by Tehmina Khan and Pavithra Siriwardha [54]. These results have important implications for business sustainability in the medium and long term. Women's situation and gender-based inequality have worsened during and after COVID-19, as has emerged in recent studies [2,9-11,50,53,55]. A study leaded by Yueping et al. [55] on the impact of COVID-19 on Chinese migrant workers who returned to China shows that women migrants were less likely than men migrants to return to the cities and also less likely to return to paid work after the pandemic outbreak, confirming the gender gap in work and salaries. Women's caregiving roles and employment in faceto-face services are the main causes of their withdrawal. Thus, the COVID-19 pandemic has caused a setback in the progress made in pre-pandemic times in advancing Chinese rural women's position in the labour market. Similar findings are shown in the study on COVID-19 and the gender gap in work hours, done by Caitlyn Collins et al. [56]. Due to the COVID-19 pandemic, caregiving responsibilities for working parents have increased; this research shows that mothers with young children have reduced their work hours four to five times more than fathers. Consequently, the gender gap in work hours has grown by $20-50 \%$. These findings indicate yet another negative consequence of the COVID-19 pandemic, highlighting the challenges it poses to women's work hours and employment.

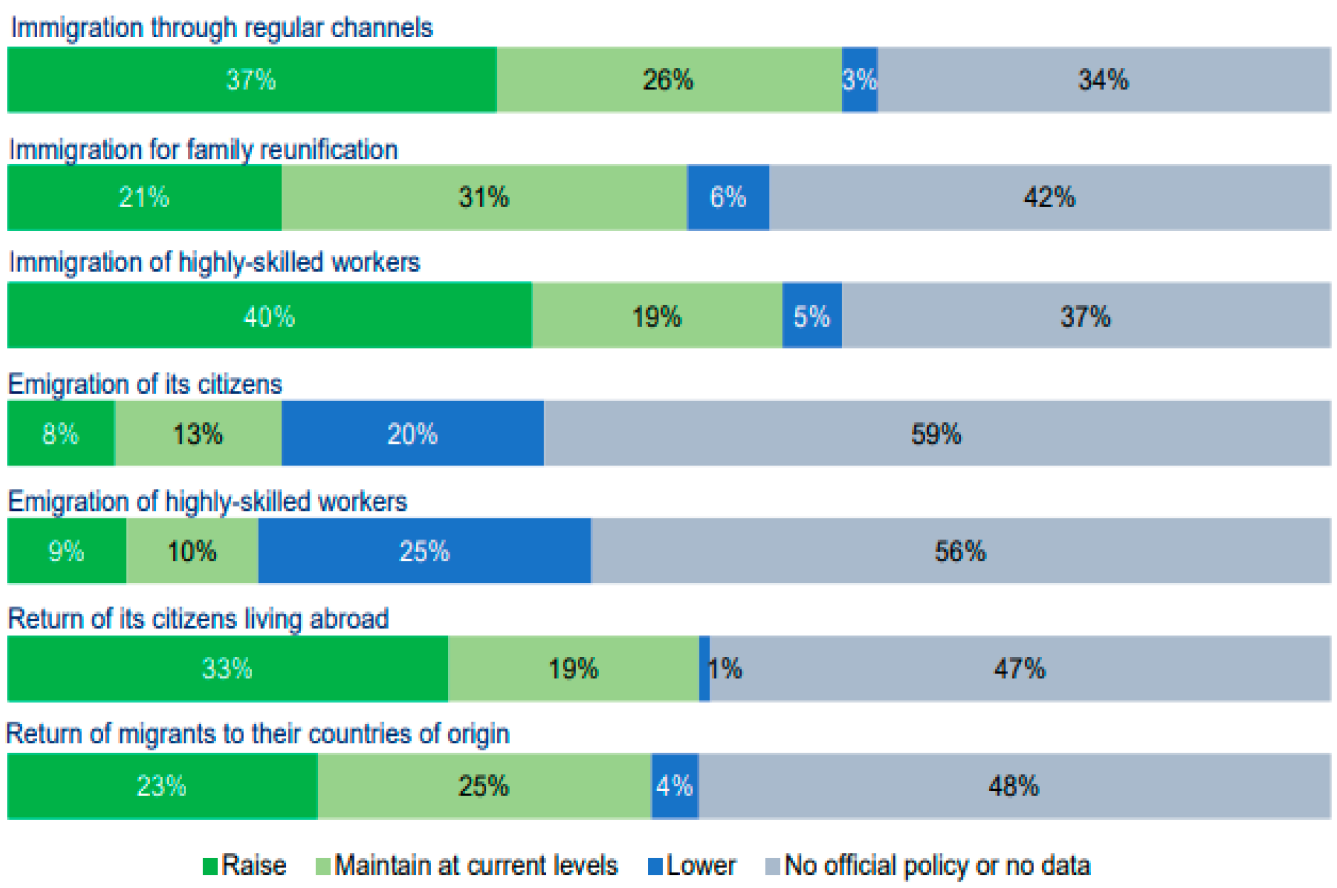

Figure 6. Percentage of governments with policy measures concerning the annual level of immigration, emigration and return. Source: United Nations, Department for Economic and Social Affairs (UNDESA), Population Division, United Nations, 2019.

On the one hand, among the studies on the impacts of COVID-19 and human mobility, we can find the Indian case, which was carried out by Priyadarshini and Chaudhury [57], in 
which the return of Bihari migrants (India) after the COVID-19 lockdown is described. This process of return seemed the logical corollary of the lockdown for daily waged migrants, who constitute the majority of the internal migrant population. Yet, unlike the Government's drive to rescue and save its international migrants from the Coronavirus pandemic, there seemed to be no preparedness to arrange for its internal migrants' safe return to their homes. On the other hand, data on the Spanish situation linking human mobility and the impacts of the COVID-19 pandemic are still little explored. In the Spanish context, Silvia Marcu [11] analysed the link between human mobility, pandemic and sustainability in Romanian mobile citizens in Spain. This researcher claims that sustainability could act as a driver in times of crisis, contributing to the creation of new models of resilient mobility. Her conclusions defend respect for the Sustainability Development Goals regarding human mobility and emphasize the role of people on the move as sustainable actors, creating new ways for human mobility to continue existing during the pandemic. Other studies are conducted on the post-COVID-19 Spanish situation and its impacts on mental health. The research carried out by González et al. [50] highlights that depression reached higher levels than ever, COVID-19 had a strong impact on mental health throughout. Women and youth have been most affected by the pandemic. Loneliness and well-being are key variables in predicting mental health impact.

\section{Methodological Strategy}

This paper contributes to the importance of emigration and return migration as phenomena linked to human mobility and sustainability in the context of the COVID-19 pandemic. To that end, I used a flexible qualitative methodology, through the application of the life-history method [58], in order to have an overall picture of respondents' lives along both geographical and historical lines, from a retrospective life-course perspective [59], combining the spatial, temporal and biographical dimensions [60] (p. 103). In order to compare the respondents' experience I carried out a focus group with migrant women returnee and another focus group with experts on migration and human mobility, as well as in qualitative methodologies of research, from various universities located in Italy, Spain and Chile. The information obtained allowed the construction of a typology to be adjusted and better validated. The interviewing process was carried out between January 2021 and May 2021. The focus group with respondents and the focus group with experts on migration and human mobility were carried out in July 2021. Moreover, the gender perspective was adopted as a transversal approach from the flexible design of the study to the data collecting and analysis. The interviews were operationalized with focus on three main dimensional axes: (a) macro-structural elements influencing the structure of opportunities and constraints in the return framework; (b) meso-relational and systemic, and the fostering and hindering factors influencing mobility processes; and (c) micro-dimension, linked to the individual and subjective experience of the whole mobility process, based on perceptions, imaginaries, desires, aspirations and expectations of highly educated Spanish women linked to the return experience.

Moreover, within the life histories I have analysed pre-migratory and return motivations in women's mobility process, as well as the analysis of different domains of their lives (such as: learning, training, professional paths, couple and family construction trajectories, and personal development and empowerment). Due to the small sampling, life-history analysis is the most complete method in qualitative research design to deepen simultaneously into several respondents' life domains. The interviewees spoke about their whole mobility trajectory from different angles, and the analysis was conducted on the multidimensional macro, meso and micro-level dimensionality through the lens of the migratory career, which allows me to design a multidimensional prism for the identification of macro, meso and micro structures of opportunities and constraints, and a typology based on the types of return and the impact of COVID-19 on them (Figure 6).

Since its reconceptualization carried out by Martiniello and Rea [18], the migratory career analytical tool has been a valuable methodology for understanding the articulation 
of different dimensions, such as personal aspirations, professional expectations, structural hindering and fostering factors related to the migration process. Therefore, it is suitable for the analysis of the emigration and return migration of respondents to the home country. This analysis allows the main aim of this study: to understand better the hindering and fostering factors related to the experience of reintegration of Spanish SIE returnee women, and to respond better to the challenge of crossing macro/structural factors with micro/subjective determinants. The analysis of the interviews was carried out by an inductive method, using detailed readings of sentences and data to derive concepts and themes and make co-generative interpretations [61]. The interpretative approach allows respondents to be positioned at the centre of the meaning-making practice in the research and knowledge-construction process and focuses on the analytical information collected in an on-going process, showing how respondents' narratives create observable outcomes.

\section{Respondents' Profiles: Selection and Recruitment Criteria}

The respondents are Spanish female professionals who emigrated in a Self-InitiatedExpatriation situation and returned before (7) and during (3) the pandemic period (Table 2). The respondents were selected through the following criteria: (a) having Spanish nationality; (b) having a high educational level (university degree at least); (c) being Self-Initiated Expatriate (SIE); (d) been living abroad at least between two and three years; (e) having work experience abroad. The selection was carried out through the snowball technique, starting from key informers. Key informers are linked to leaders of migrant associations in Spain and the interviewed are linked to the United Nations, NGOs and international cooperation universe. The women interviewed are from seven different geographical areas in Spain: in particular, participants are from Galicia (2), Cataluña (1), the Basque Country (3), Andalucía (1), Comunidad Valenciana (1), Comunidad de Madrid (1) and Castilla La Mancha (1). The respondents' motivations for their SIE situation are linked to new professional challenges, work or internships expatriation followed by professional career development in the host country. The motivation for return is based on two decisionmaking processes: (a) better life style and condition in the country of origin, therefore, voluntary return migration; (b) COVID-19 forced return migration. In the following table (Table 2) an overview of interviewed returnee women's background and information on their educational and professional profiles is given in detail.

Respondents used the mobility channels of Spain-Latin America and Spain-Caribbean, mostly. Before betting on an international work experience, two of them were in an Erasmus international exchange experience in another European country; others had an international internship experience converted into a job experience with the possibility of professional career development. Half of the target group has transited through more than one country. The sectors of expertise linked to their education are heterogeneous, representing both humanities and STEMs, in detail: history, geography, political science, journalism, cultural project management, languages and literature, informatics, engineering, management and administration. Most of them hold a Master's degree or a specialization in international cooperation for development studies and professional experience in this field. 
Table 2. Respondents' Profiles and Migratory Trajectories.

\begin{tabular}{|c|c|c|c|c|}
\hline $\begin{array}{l}\text { Returnee Women in Spain } \\
\text { and Migration Trajectories }\end{array}$ & Age and Status & $\begin{array}{l}\text { Educational } \\
\text { Profile }\end{array}$ & $\begin{array}{l}\text { Professional Profile in } \\
\text { SIE Situation }\end{array}$ & Return Migration Situation \\
\hline $\begin{array}{l}\text { 1: Galicia-Dominican } \\
\text { Republic_Galicia }\end{array}$ & $\begin{array}{l}42 / \text { married } \\
2 \text { children }\end{array}$ & Geographer & $\begin{array}{l}\text { International Organization } \\
\text { Officer-Gender }\end{array}$ & Unemployed in reskilling \\
\hline 2: Galicia—Cuba—Galicia & $36 /$ married & $\begin{array}{l}\text { Political Science \& } \\
\text { Management }\end{array}$ & $\begin{array}{l}\text { International Organization } \\
\text { Officer-Food }\end{array}$ & $\begin{array}{l}\text { Employed in Private Sector } \\
\text { Firm }\end{array}$ \\
\hline $\begin{array}{l}\text { 3: Cataluña-Dominican } \\
\text { Republic-Cataluña }\end{array}$ & $\begin{array}{l}42 / \text { married } \\
1 \text { child }\end{array}$ & $\begin{array}{l}\text { Political Science \& } \\
\text { Management }\end{array}$ & $\begin{array}{l}\text { Local } \\
\text { Development }\end{array}$ & $\begin{array}{l}\text { Employed in Private Sector } \\
\text { Firm }\end{array}$ \\
\hline $\begin{array}{l}\text { 4: Basque Country-Peru- } \\
\text { Dominican Republic- } \\
\text { Panamá-Basque Country }\end{array}$ & $35 /$ single & Design Engineer & $\begin{array}{l}\text { Conflicts and Natural } \\
\text { Disaster Officer }\end{array}$ & $\begin{array}{l}\text { Employed in International } \\
\text { NGO }\end{array}$ \\
\hline $\begin{array}{l}\text { 5: Basque Country- } \\
\text { Cuba-Basque Country }\end{array}$ & $\begin{array}{l}38 / \text { single mother } \\
1 \text { child }\end{array}$ & $\begin{array}{l}\text { Humanities } \\
\text { \& History }\end{array}$ & $\begin{array}{l}\text { International Organization } \\
\text { Officer-Culture }\end{array}$ & $\begin{array}{l}\text { Part-time job in NGO } \\
\text { for life-work balance }\end{array}$ \\
\hline $\begin{array}{l}\text { 6: Basque Country- } \\
\text { USA-Basque Country }\end{array}$ & $33 /$ single & $\begin{array}{l}\text { Communication \& } \\
\text { Journalism }\end{array}$ & $\begin{array}{l}\text { Basque } \\
\text { Government } \\
\text { in USA } \\
\text { (Internship) }\end{array}$ & $\begin{array}{l}\text { Employed Fixed Term in the } \\
\text { Public Sector } \\
\text { (Basque Government) }\end{array}$ \\
\hline $\begin{array}{l}\text { 7: Andalucía- } \\
\text { France-Morocco- } \\
\text { Andalucía }\end{array}$ & $\begin{array}{l}38 / \text { single mother } \\
1 \text { child }\end{array}$ & $\begin{array}{l}\text { Arabic Language \& } \\
\text { Literature }\end{array}$ & $\begin{array}{l}\text { NGO } \\
\text { (Internship) }\end{array}$ & Unemployed in reskilling \\
\hline $\begin{array}{l}\text { 8: Comunidad Valenciana } \\
\text {-Dominican Republic- } \\
\text { Comunidad Valenciana }\end{array}$ & $\begin{array}{l}53 / \text { single mother } \\
1 \text { child }\end{array}$ & $\begin{array}{l}\text { Communication, ICT \& } \\
\text { Cultural } \\
\text { Management }\end{array}$ & $\begin{array}{l}\text { Digital } \\
\text { Communication } \\
\text { Officer }\end{array}$ & $\begin{array}{l}\text { Unemployed } \\
\text { (Received support } \\
\text { measures in the Spanish } \\
\text { return migration framework) }\end{array}$ \\
\hline $\begin{array}{l}\text { 9: Comunidad de } \\
\text { Madrid-Dominican } \\
\text { Republic-Morocco- } \\
\text { USA-Belgium }\end{array}$ & $35 /$ single & Lawyer & Lawyer Private Sector & $\begin{array}{l}\text { Employed in Private } \\
\text { Sector }\end{array}$ \\
\hline $\begin{array}{l}\text { 10: Castilla La Mancha- } \\
\text { Dominican Republic }\end{array}$ & $45 /$ single & MBA & $\begin{array}{l}\text { Economy \& Local } \\
\text { Development }\end{array}$ & $\begin{array}{l}\text { Employed in Private Sector } \\
\text { Firm }\end{array}$ \\
\hline
\end{tabular}

Note: Table 2 is based on the fieldwork and shows the respondents' educational and professional profiles, sector and status of occupation in host country and return situation in Spain.

Their expatriation experience is linked to an international organization (United Nations, European Commission, NGOs, etc.), to a non-governmental organization or to a multinational company. In the home country, they are currently working in different fields and sectors of labour market: in some cases, their jobs are not in a matching situation with their educational profile; in other cases, some women are unemployed. Hereafter, I give some socio-demographic data, in order to understand the profiles of the women interviewed. Women interviewed are 40 years old on average and the average at the moment of their expatriation was 26 years old; the average they spent abroad as Self-Initiated Expatriates is around nine years. Informer consent was proposed and signed by each interviewee before starting the life-history procedures of interviewing; the interviews were conducted in two or three sessions, depending on the time availability and other limitations, due to family conciliation factors. Given the pandemic situation, and with the help of new technologies, implementation of which has increasingly facilitated long-distance contacts and virtual meetings, I was able to conduct the life histories in many sessions online, via Hangouts, Zoom, Whatsapp video and many other Apps. The duration was around $45 \mathrm{~min}$ per session. After that, they would send me their Facebook and Instagram profiles to access and send pictures about specific life junctures, which represented turning points in their life courses. During the interviews, women's attitudes were very collaborative and proactive, allowing fluidity in the process of collecting data. Finally, the information and data collected were structured respecting the same structural levels. The life histories were verbatim transcripts, and a complex coding system, developed by the researcher, was assigned to each informer in order to respect their anonymity and privacy during the whole process. 


\section{Analysis and Discussion: Return Migration, Gender and Sustainability during the COVID-19 Pandemic}

Return migration has a complex problem of reintegration and readaptation process, worsening the vulnerability of returnee women, due to the intersection of the category of returnee with gender. Linked to identity perceptions, returnee women feel strangers in their own country; having adopted cross-cultural identification and codification processes, they are trapped in some space- and time-balancing dynamics. As follows, I offer an analysis of the fieldwork in relation to the interconnection between the analytical axes of the present study, approached from the gender perspective and the analytical lens of the migratory career, in order to address another important relationship between the pandemic, the return of highly educated women and sustainability.

\subsection{Motivations for Return}

Before entering in the macro, meso and micro-analytical data process, it would be worth to understand the reasons for emigration and return in the respondents, as data on expats returning by gender might shed light on the gendered impact relating to job loss during the pandemic. You can then connect experiences on return to the initial "blow" of losing the position/job overseas (Table 3).

Table 3. Respondents' Motivations for Emigration and Return.

\begin{tabular}{|c|c|c|c|c|}
\hline Returnee Women in Spain & $\begin{array}{l}\text { Motivation for } \\
\text { Expatriation }\end{array}$ & Motivation for Return & $\begin{array}{c}\text { Forms for } \\
\text { Return to Spain }\end{array}$ & $\begin{array}{l}\text { Return Migration } \\
\text { Situation }\end{array}$ \\
\hline $\begin{array}{l}\text { 1: Galicia-Dominican } \\
\text { Republic-Galicia } \\
\text { 42/married, } 2 \text { children }\end{array}$ & $\begin{array}{l}\text { Professional } \\
\text { Opportunities \& } \\
\text { Job Experience }\end{array}$ & Husband fix work in Spain & $\begin{array}{l}\text { International } \\
\text { Organization Officer } \\
\text {-Gender }\end{array}$ & Unemployed in reskilling \\
\hline $\begin{array}{l}\text { 2: Galicia-Cuba-Galicia } \\
\text { 36/married }\end{array}$ & $\begin{array}{l}\text { Professional } \\
\text { Opportunities \& } \\
\text { Job Experience }\end{array}$ & Better life's conditions & $\begin{array}{l}\text { International } \\
\text { Organization Officer } \\
\text {-Food }\end{array}$ & $\begin{array}{l}\text { Employed in Private } \\
\text { Sector Firm }\end{array}$ \\
\hline $\begin{array}{l}\text { 3: Cataluña-Dominican } \\
\text { Republic-Cataluña } \\
\text { 42/married, } 1 \text { child }\end{array}$ & $\begin{array}{l}\text { Professional } \\
\text { Opportunities \& } \\
\text { Job Experience }\end{array}$ & Better life's conditions & $\begin{array}{l}\text { Local } \\
\text { Development }\end{array}$ & $\begin{array}{l}\text { Employed in Private } \\
\text { Sector Firm }\end{array}$ \\
\hline $\begin{array}{l}\text { 4: Basque Country-Peru } \\
\text { —Dominican Republic- } \\
\text { Panamá-Basque Country } \\
\text { 35/single }\end{array}$ & $\begin{array}{l}\text { Professional } \\
\text { Opportunities \& } \\
\text { Job Experience }\end{array}$ & Better work conditions & $\begin{array}{l}\text { Conflicts and Natural } \\
\text { Disaster Officer }\end{array}$ & $\begin{array}{l}\text { Employed in International } \\
\mathrm{NGO}\end{array}$ \\
\hline $\begin{array}{l}\text { 5: Basque Country- } \\
\text { Cuba-Basque Country } \\
38 / \text { single mother, } 1 \text { child }\end{array}$ & $\begin{array}{l}\text { Professional } \\
\text { Opportunities \& } \\
\text { Job Experience }\end{array}$ & Better life's conditions & $\begin{array}{l}\text { International } \\
\text { Organization Officer } \\
\text {-Culture }\end{array}$ & $\begin{array}{l}\text { Part-time job in NGO } \\
\text { for life-work balance }\end{array}$ \\
\hline $\begin{array}{l}\text { 6: Basque Country-USA } \\
\text {-Basque Country } \\
33 \text { / single }\end{array}$ & $\begin{array}{l}\text { Professional } \\
\text { Opportunities \& } \\
\text { Job Experience }\end{array}$ & $\begin{array}{l}\text { Elderly } \\
\text { parents }\end{array}$ & $\begin{array}{l}\text { Basque } \\
\text { Government } \\
\text { in USA } \\
\text { (Internship) }\end{array}$ & $\begin{array}{l}\text { Employed Fixed Term in } \\
\text { the } \\
\text { Public Sector } \\
\text { (Basque Government) }\end{array}$ \\
\hline $\begin{array}{l}\text { 7: Andalucía-France } \\
\text {-Morocco-Andalucía } \\
\text { 38/single mother, } 1 \text { child }\end{array}$ & $\begin{array}{l}\text { Professional } \\
\text { Opportunities \& } \\
\text { Job Experience }\end{array}$ & Better life's conditions & $\begin{array}{l}\text { NGO } \\
\text { (Internship) }\end{array}$ & Unemployed in reskilling \\
\hline $\begin{array}{l}\text { 8: Comunidad Valenciana- } \\
\text { Dominican Republic- } \\
\text { Comunidad Valenciana } \\
53 / \text { single mother, } 1 \text { child }\end{array}$ & $\begin{array}{l}\text { Professional } \\
\text { Opportunities \& } \\
\text { Job Experience }\end{array}$ & $\begin{array}{l}\text { Elderly } \\
\text { parents }\end{array}$ & $\begin{array}{l}\text { Digital } \\
\text { Communication } \\
\text { Officer }\end{array}$ & $\begin{array}{l}\text { Unemployed } \\
\text { (Received support } \\
\text { measures in the Spanish } \\
\text { return migration } \\
\text { framework) }\end{array}$ \\
\hline $\begin{array}{l}\text { 9: Comunidad de } \\
\text { Madrid-Dominican } \\
\text { Republic-Morocco-USA } \\
\text {-Belgium } \\
\text { 35/single }\end{array}$ & $\begin{array}{l}\text { Professional } \\
\text { Opportunities \& } \\
\text { Job Experience }\end{array}$ & $\begin{array}{l}\text { Elderly } \\
\text { parents }\end{array}$ & Lawyer Private Sector & $\begin{array}{l}\text { Employed in Private } \\
\text { Sector }\end{array}$ \\
\hline $\begin{array}{l}\text { 10: Castilla La Mancha } \\
\text {-Dominican Republic } \\
45 / \text { single }\end{array}$ & $\begin{array}{l}\text { Professional } \\
\text { Opportunities \& } \\
\text { Job Experience }\end{array}$ & Better life's conditions & $\begin{array}{l}\text { Economy \& Local } \\
\text { Development }\end{array}$ & $\begin{array}{l}\text { Employed in Private } \\
\text { Sector } \\
\text { Firm }\end{array}$ \\
\hline
\end{tabular}

Note: Table 3 is based on the fieldwork and shows the respondents' motivations for emigration and return migration to their home country, Spain. 
The following section is based on the analysis of the collected data, followed by the discussion of them, based on the three axes of (a): macro-structural impacts of COVID-19 on returnee women, mainly focused on the structures of opportunities and constraints in labour market reincorporation and educational opportunities; (b) meso-analytical impact of COVID-19, return, and relations and copying strategies for readaptation to the context of return; and (c) micro-analytical level of perceptions, subjects' individual aspirations, expectations and desires. In the following outline (Table 4), the main findings are organized according to the axes of analysis in the multidimensional approach, based on the COVID-19 situation as the aggravating factor in the return migration for Spanish women.

Table 4. Axes of Analysis.

\begin{tabular}{|c|c|c|c|}
\hline Opportunities & & Axes of Analysis & Constrains \\
\hline $\begin{array}{l}\text { Re-organization of professional profile } \\
\text { adapted to the labour market situation } \\
\text { through education: } \\
\text { - } \quad \text { Re-skilling } \\
\text { - } \quad \text { Up-skilling } \\
\text { - } \quad \text { Digitalization }\end{array}$ & (a) & Macro-structural dimension & $\begin{array}{ll}- & \text { Job-education mismatch } \\
- & \text { Job experience at local level mismatch } \\
- & \text { Underqualification/Overqualification } \\
- & \text { Unemployment } \\
- & \text { Precarious work } \\
- & \text { (Permanent) part-time jobs } \\
- & \text { Underpaid job }\end{array}$ \\
\hline $\begin{array}{l}\text { - To rethink the management of the } \\
\text { COVID-19 pandemic with a } \\
\text { gender-sensitive approach } \\
\text { - To rethink methods of work for } \\
\text { life-work balancing } \\
\text { - To rethink the use of ICTs for work, } \\
\text { services, and for sustainable ties and } \\
\text { connections }\end{array}$ & (b) & Meso-relational dimension & $\begin{array}{ll}\text { - } & \text { Inadequate heath \& care system } \\
\text { - } & \text { Non-gender-sensitive policies } \\
\text { - } & \text { Inexistent measures for life-work } \\
\text { balance } \\
\text { - } \quad \text { Maternity \& caring }\end{array}$ \\
\hline $\begin{array}{ll}- & \text { Activation of resilience } \\
- & \text { Activation of personal coping strategies } \\
- & \text { Rethinking life's priorities } \\
- & \text { Rethinking life's projects } \\
- & \begin{array}{l}\text { Agency as key factor for the } \\
\text { reintegration process }\end{array}\end{array}$ & (c) & Micro-subjective dimension & $\begin{array}{ll}- & \text { Frustrating aspirations } \\
- & \text { Wrong expectations } \\
- & \text { Loneliness \& isolation } \\
- & \text { Mental health problems }\end{array}$ \\
\hline
\end{tabular}

Note: Table 4 derived from findings, according to the analysis of life histories and organized in three main axes and dimensions.

\subsection{Macro-Analytical Dimension from a Gender Perspective}

According to Liu-Farrer et al. [47], a "disjuncture between the logic embedded in national employment systems and those of the globally mobile workforce despite the national policy to attract and retain highly skilled workers" (p. 2246) is found in the context of return in the Spanish case. In that sense, the results of this study suggest that in the case of returnee women there is a disjuncture between job-education matching both locally and globally exists. This also means that highly educated women who return to their country of origin are performing a waste of skills and capabilities during the human mobility process and they risk long-term immobility.

In addition to that, the structures of power/oppression have a negative impact on their personal and professional development, and such existing difficult reality has been increased by the impact of the COVID-19 pandemic. Therefore, innovative measures and more sustainable policies addressed to an efficient reintegration of returnee women are urgently required, in order to fight against the rise of overqualification and permanent loss of skills in the origin countries [1,41,42]. Such policies are urgent to respond to the negative impact of the COVID-19 and make human mobility more sustainable. 
4.2.1. Sustainability, Return Migration and Labour Market Re-Integration in the COVID-19 Pandemic

According to IOM [62], reintegration is a complex and multidimensional process, encompassing social, economic, professional and family reallocation and readaptation, which requires a holistic and a needs-based approach. There are different interconnected factors impacting subjects' return and reintegration process at macro level, linked to the economic and socio-political levels; at, micro level, intra-subjective dimension; and meso level, related to psychosocial factors crossing individuals, communities and structural dimensions. Therefore, reintegration is sustainable when returnees have reached levels of socio-economic stability and psychosocial well-being in their socio-communitarian environments that allow them to cope with (re)migration drivers. By having achieved sustainable reintegration, returnees are able to make further migration decisions as a matter of choice rather than necessity [63].

During the COVID-19 pandemic, returnee women claim their place in their home country both at macro and meso levels of integrations. They experience a gap in the labour-market reintegration process, for different reasons, such as maternity, life-work balance, part-time jobs, low salaries, no job-education matching conditions, no updated education fit with a different or changing local labour market. Thus, readaptation processes are also about the application of coping strategies to face the gap in the local labour market upon return, which is changing and does not fit with the job experience or educational profile women have developed during their emigration, as is stressed by evidence in previous research [2,11]. Respondents have to face a professional profile readjustment process to start their reintegration into labour market, which has implications for their identity transformation and family adaptation process. Their strategies, thus, are mostly reskilling or upskilling, in order to best match with the local labour market demand. Nevertheless, in most of the cases analysed, they have long periods of frustrating waiting and unemployment rates. Finally, this study confirms that the limbo situation is not sustainable for human mobility: emigration and return migration strategically are not profitable ways for personal and professional development.

When COVID-19 started, I had moved from Bilbao to Madrid, where I found a job after unemployment. I thought this job would have given me stability and independence, but I was in a chaotic and collapsed Madrid. I lived a long time of isolation, teleworking from home (...) suddenly, it seemed the world had stopped and I had to return again to my parents' home because it was impossible living in Madrid. (Humanitarian, 35 years old, Basque Country)

Related to "The Feminist Plan for Sustainability and Social Justice" and the Beijing Strategy [14,64], produced by UN Women, the results of this study confirm the urgent need for transformative policies for a more equal and sustainable future for women and girl migrants and returnees. Respondents' suggestions provide similar evidence, addressed to the necessity of "context-specific policy pathways, tailored political strategies and alliances, and financing". The COVID-19 pandemic may represent the best opportunity to rethink values and economies in a democratic way, to solve the problem of job-education mismatch in human mobility, to make the reintegration paths of migrant women and returnees more sustainable than before; and women can stay at the front line in the response to the virus and the recovery plan for sustainability. Related to this, the Beijing strategy is a relevant instrument to foster the agenda for gender equality, which has seen a stop in its slow development. In the global agenda, leadership and salary gaps are to be filled in order to achieve such a sustainability; in relation to human mobility, and in particular to return, more and better measures for reintegration of women in their country of origin are to be implemented urgently for better social and personal development. It has been noted that returnee women were working in precarious conditions and underpaid jobs, despite their high level of education/skills, as some of the interviewed women indicated: 
I had different problems of reintegration to the local labour market, indeed, I felt frustrated and I was obliged to accept underpaid jobs in a situation of underqualification. (Administration, 45 years old, Ciudad Real)

There are no measures for helping life-work balance, no measures appropriate to returnees, linked to opportunities of orientation in the return context, offer-demand of the local labour market, orientation on reskilling opportunities and self-employment opportunities, etc. (Psychologist, 35 years old, Andalucía)

\subsubsection{Sustainability, Return Migration and Maternity}

I categorized the maternity in the context of return migration because it is embedded in the systemic-structural and social-construction approach. Maternity is linked to a sociopolitical structure of power and oppression. Thus, the most relevant factor in returnee women's narratives is found in the relationship between maternity, parenting, caring and COVID-19, and is linked to the lack of access to the health centres and on-site health-care system. Mothers claim it is difficult to carry out simple functions related to the regular check-ups on new-born babies and worse cases rose. They claimed the inexistence of health and care support and the problems resulting from this situation, which are important to mitigate the risks of nurturing and caring.

My experience as a mother during the pandemic is heavy because of the lack of health and care systems, all the effort for the struggle for the coronavirus made my maternity experience more and more difficult. (Economist, 39 years old, Basque Country)

I found a neglected public health system, the appointment with doctors for regular checkups delay several days, also weeks. Telephone consultations were quite impossible to carry out with a new-born baby. So I stopped doing things to be aware on the telephone call, because if you miss the only call of the day from the health centre, you don't have another chance, and you have to repeat the whole process and wait again for long time. (Unemployed, 41 years old, Galicia)

\subsection{Meso-Analytical Dimension from a Gender Perspective}

In this axis I explored, on the one hand, perceptions, imaginaries, aspirations and expectations on an intra-subjective dimension in returnee women. Returnee women are unaware of the risks lived in the pandemic, as it is shows in Silvia Marcu [11] (p. 14). On the other hand, I explored the relation between external and internal constellation in which returnee women are embedded during the COVID-19 and recovery times. In that sense, there are two relevant themes on the inter-subjective life experience in the context of return migration: (1) poor social relations are the prominent emerging theme in the returnee women's lives, as well as feelings of isolation and frustration; (2) copying strategies and interaction with social and structural factors, hindering or fostering women's empowerment and adaptation processes.

\subsubsection{COVID-19, Return Migration and Loneliness}

Isolation and poor social relations are the prominent emerging theme in the returnee women's narratives. Indeed, isolation and loneliness are widespread emotions among migrants and returnees in normal situations; but they are exacerbated by pandemic and lockdown, which have reinforced physical and psycho-social isolation, making it persistent and more-or-less permanent. This is a risk factor influencing human mobility in dignified conditions, both for low-educated and highly educated professionals on the move. In the case of women, they suffer from multiple discriminations and stereotypes linked to gender roles in society and other discriminatory categories. In fact, gender, maternity, unemployment, low incomes and single parenthood are among the more discriminatory factors, which strengthen the hazardous risks affecting women on the move in times of pandemic. The pandemic has led women to reflect on their migration, as in Silva Marcu has also reported [11] (p. 14). 
A humanitarian professional, always on the move, said:

I arrived from Africa during the COVID-19 crisis, as they said it was not safe. But ultimately I felt safer than in Madrid where there was chaos (...). I experienced difficult times to reintegrate my professional life, and I was completely isolated in Madrid, it was so hard... (Humanitarian, 35 years old, Basque Country)

The Coronavirus crisis found me pregnant, so the childbirth and the postpartum were an additional agony to the difficult situation we were living in (... ). I was alone, with my oldest daughter and the new-born baby, because my husband worked all day and the lockdown was an extra agony for me and for my family, because I was isolated, with a new-born baby in the worst moment ever of the history of the contemporary world, the anxiety about the illness and the anxiety for my oldest child, the lack of social relationships with her peers, her education, her environment, finally, I was overwhelmed. (Unemployed, 41 years old, Galicia)

\subsubsection{Dependent Children and Aging Parents}

One of the most common reasons for return migration, which could be situated in the middle way between voluntary and forced in COVID-19 times, is the caring and risks based on infections and illness in the most vulnerable population, such as aging parents and dependent children, as can be seen in the following lines:

I decided to return to Spain because I was very worried for my aging parents and for my daughter too, for her security and protection. (Unemployed, 53 years old, Valencia)

I came back for my aging father. He is 80 years old and, when he was affected by COVID-19 and hospitalized, I was afraid and I imagined the worst. (Lawyer, 35 years old, Madrid)

\subsubsection{Coping Strategies in Returnee Women}

The COVID-19 situation has worsened returnee women's life conditions, increasing precarious situations, in particular in single-mother families. Vulnerability is a factor that is not present in the literature and scholars have given scant attention to this risk element in highly educated women's mobility, because they are associated, traditionally, to privileged migration flows. Nevertheless, by deepening into the analysis of privilege mobilities from a gender perspective, it could be claimed that there are different factors influencing the migratory career of highly educated and SIE women.

I have to say that this situation reinforces my self-image, which I'm able to face hard situations, to be alone in isolation and take care of myself. I feel frustration during lockdown (...), but I have to say that I confirm to myself that I have personal tools as the arts that helped me to stay connected with my inner self and do not feel panic, however. (Humanitarian, 35 years old, Basque Country)

The main strategies I activated during the lockdown with my two children were the caring and the reskilling, in order to prepare my reintegration into the labour market after this crisis Coronavirus crisis. (Unemployed, 41 years old, Galicia)

I used digital methods and high technologies more than ever, in order to search for connectivity. Social relations are important and I was able to stay in touch with family and friends more than ever, due to the celerity and comfort in communications, (...) but also to find job opportunities or educational perspectives to restart after COVID-19. (Lawyer, 35 years old, Madrid)

\subsubsection{Skill-Building, Returnee Women and Sustainability}

As I approached the concept of skill-building as a potential in the human mobility process, it may be a key issue in the reconstruction of returnee women's professional profiles and their labour market reintegration processes. Skills acquired during crossborder mobility play a key role in the reintegration process of migrant and returnee women 
and their roles as agents for local development, which is underscored by governments. In that sense, human mobility can be conceptualised as a strategy of the human and social capital improvement process $[65,66]$. Returnee women's claim that, in spite of the difficulties and discrimination as young women and inexperienced professionals, who emigrate to improve their curriculum vitae, the expatriation experience is a completely successful experience in terms of personal empowerment, as described as follows:

I want to remember all the people I met and I would take with me the enriching life experience which make me empowered. The difficulties which I faced, the different language and the different cultures I live in (...) and the paradox that you expect something different from each country, I take as a life experience that make me better person... (Unemployed, 38 years old, Andalucía)

More respondents emphasised personal empowerment:

The balance of this experience is more than positive. The key point is to have had the opportunity to know new cultures, to be able to live abroad and manage the idiosyncrasy and the difficulties (...); to be able to understand the diversity and to meet new people (...) in sum, the personal empowerment and human development is high. (Unemployed, 53 years old, Comunidad Valenciana)

The added value of my expatriation experience is not linked to the skill-building process, which is very high and enriching, but I think that it is in my work experience in high quality environments, multicultural settings, for me as a young woman was the best experience ever. In addition, the opportunity to expatriate from Spain was accompanied by the best work opportunity in international organizations (... ). (Humanitarian, 35 years old, Basque Country)

My experience as an expatriate was the best, the creation of emotional networking in another country (...). (Linguistics, 33 years old, Basque Country)

Respondents' suggestions lead to some innovative ways to reconstruct their capabilities and renew their skills-such as in-person counselling, post-arrival structure of assistance, educational reorientation, skills updating, including legal aid-are reduced to a minimum or subjected to delay. However, online consultations during the lockdown have helped in the clarification process on the opportunities available, and have helped to overcome some barriers to accessing supports and measures.

\subsection{Micro-Analytical Dimension from a Gender Perspective Mental Health on Return}

Mental health in the case of returnee women is a sensitive issue; in particular, this should be stressed in returnee mothers, who face added problems of life-work balance; and personal aspirations, family expectations and job matching in the country of origin which has probably transformed its socio-economic systems and structures. COVID-19 is an added problem to the reintegration and readaptation process in highly educated returnee women. Another finding to be stressed in this paper is the reciprocal relationship between the mental health condition, human mobility and COVID-19, in order better to address measures for returnee women and their families as one of the most sensitive issues related to the COVID-19 recovery process. Mental health issues are spread among women and mothers. This study confirms the evidence found in González et al. [50] about depression reaching higher levels than ever and that COVID-19 had a strong impact on mental health throughout lockdown. In their study, in fact, women and youth have been most affected by the pandemic. The same evidence I found in the narrative of returned respondents, mothers, occupied in full-time caring and parenting activities, stressed as follows:

Depression and anxiety were becoming my best friends in the reintegration project I have with my family (...) always worried about physical health and well-being, and the socio-psychological mental health, of my baby daughters. (Unemployed, 41 years old, Galicia) 
Mental health problems are one of the big issues during the pandemic; difficult experiences such as motherhood and parenting also worsened and raised other mental health problems, not only linked to gender roles, but also to fear for their children's lives and safety:

I am always worried for my baby boy. People touch him and I can't stop it. So, I start cleaning him all the time (...), people don't understand that there is a virus and we are not vaccinated and he is so defenceless (...) Sometimes, I think I am becoming a prisoner of these fears, obsessions and manias. (Economist, 39 years old, Basque Country)

I was worried for my family, my parents are getting older and I feel fear and frustration about their situation linked to Covid-19. (ICTs, 53 years old, Valencia)

Therefore, I would stress that mental health and resilient strategies against loneliness and consequent anxiety have a key role in fostering sustainable solutions and well-being in human mobility and return of women to their country of origin.

My return to Spain coincided with my maternity, therefore, my social relations have changed completely and I felt a great loneliness. People without family went far away and other mothers reached out to me, but with COVID-19 this loneliness was getting deeper and deeper. (Unemployed, 38 years old, Andalucía)

The questions addressed in this paper respond to the construction of heterogeneous pictures of the situation experienced by returnee women in Spain. COVID-19 affected both their professional paths and geographical mobilities, increasing dissatisfaction among them. Moreover, maternity and life-work balance seem to be more difficult in COVID-19 times, due to the added isolation and lockdown measures, which worsen their life-condition as well as their mental health and the socio-psychological status of their children. Their professional career development has been halted in duplicate by the return to the home country and the COVID-19 pandemic, with a double-bonded effect both on personal and professional trajectories. Therefore, this study confirms that an existing gender imbalance has a central role in the management of the return migration of women to Spain, as one of the relevant hindering factors in the development of professional career paths in Spain during COVID-19. By missing a gender-sensitive approach in the public policies and supporting measures, structural problems related to multiple discriminations based on gender, educational level, maternity, status, etc. in returnee women are the most relevant hindering factors found in the macro-analytical dimension of human mobility and the blockage of human development in women.

In contrast, fostering elements for returnee women could be found in the improvement of family-building processes and the accomplishment of personal expectations in relation with the previous work experience gained abroad during the emigration period. Nevertheless, in the COVID-19 period they have encountered difficulties directly linked to heath and care for their children, in life-work balance, forcing women into unemployment, or to flexible, part-time and lower-paid jobs, which do not match their sector/level of education. Finally, a positive fostering element is to be found in their agency, as claimed in previous studies $[1,2,4]$ and their efforts to find reskilling opportunities and rewrite their professional profiles according to the demands of the local labour market; or finding other solutions as international job opportunities to be carried out through teleworking; or to rewrite their profiles through different training opportunities of reskilling and upskilling, while they are waiting for the pandemic to end and opportunities restart and reactivate.

Finally, women's agency, resilience and coping strategies are the emergent positive practices in order to face the difficulties that arose with COVID-19 and activating a reintegration process based on sustainability.

\subsection{A Typology of Return Migration in Spanish Returnee Women}

From the analysis of the interviews, and the comparison with my previous research on the professional evolution of highly educated migrant women (in the case of the Basque Country) [1], a reflection on the returnee women's trajectories and mobility patterns can 
be carried out. I identified different patterns and behaviours in the returnee women's migratory career analyses. Nevertheless, it should be reproduced in other countries to prove its fit in comparison with other people or women in return migrations in their countries of origin. The following typology (Figure 7) is based on the determinants found at the macro, meso and micro dimensions, arising from the analysis of the respondents' migratory careers. Moreover, I would stress that I identified three different behaviours, which seem to be directly linked to the impact of COVID-19 on the women's lives.

(1) The first pattern is the "steady return", which is based on the idea of permanent resettlement and reintegration. Returnee women move through a transformative personal and professional mechanism aimed at a more stable and sustainable relocation. It is linked to a high impact of COVID-19 in women's lives, in their professional career expectations or personal aspirations. This kind of return is forced by a drastic professional change or family needs (parenting, caring of elderly, for example). Strategies applied in this group of returnee women are re-skilling, up-skilling and jobs led in an international setting.

(2) The second pattern is the "flexible return", which is based on the flexible idea to re-emigrate to another geographical place. Women with this profile have no burdens (dependent children or aging parents) and they are more open to change destination country after the COVID-19 pandemic. Therefore, they show a low impact of COVID19 in their lives, due to flexible professional careers and flexible family expectations, and it can be considered a fostering factor for overcoming the difficulties that arose during the pandemic situation.

(3) The third pattern is the "chaotic return", which is based on the indecisions, disorientation situation and non-clarity about today's choices, opportunities and directions to be taken during and after the COVID-19 pandemic. This group have higher mental health problems, suffering anxiety, depression and burnout. Unemployment and life-work balance are the main issues. Women in this typology suffer from a high impact of COVID-19 in their lives. The chaotic pattern does not enable women returnees to design and develop a clear personal and professional life project, this being a hindering factor in the reintegration process.

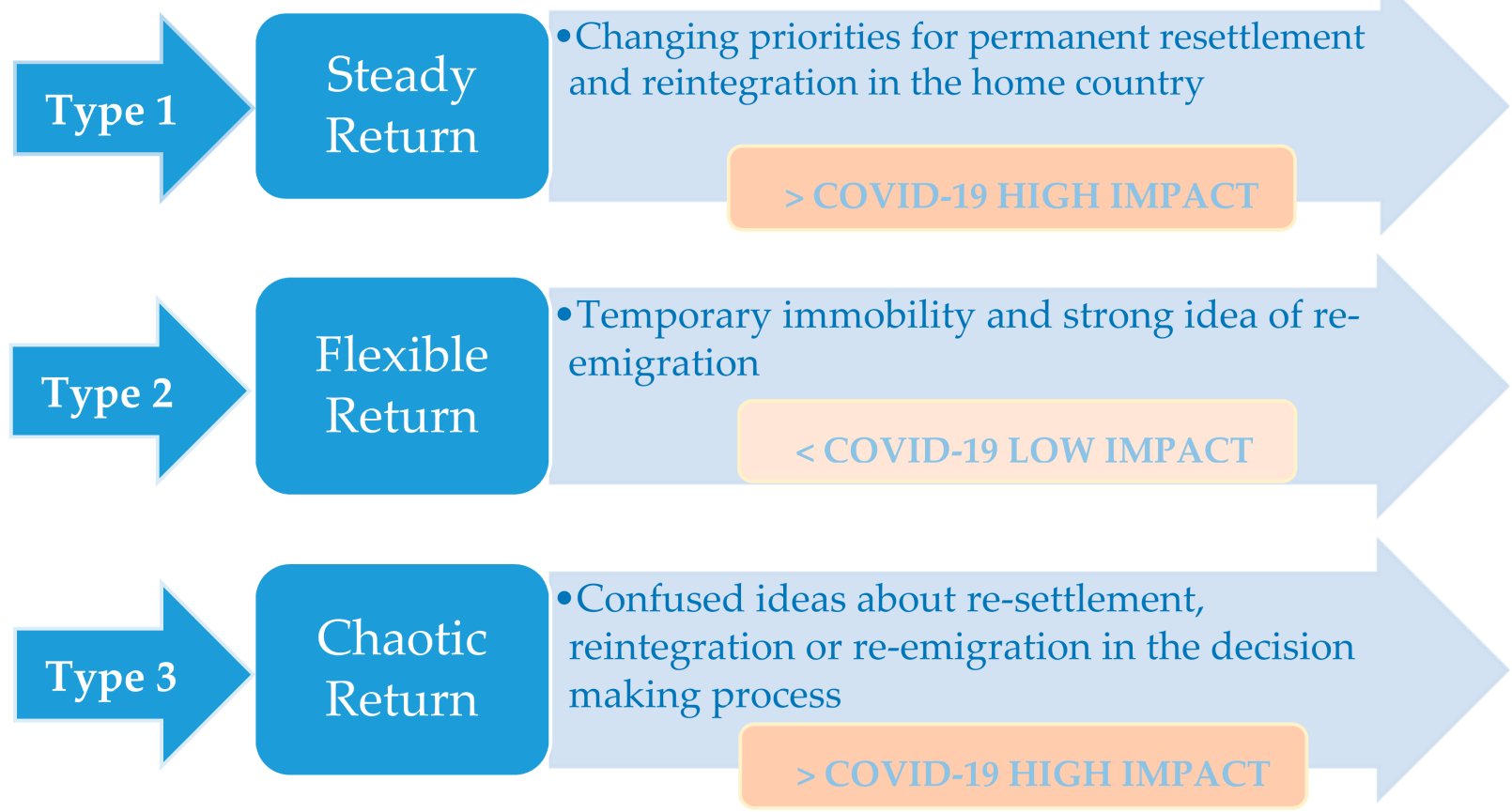

Figure 7. Typology outlined on the migratory career paths of the Spanish returnee women interviewed. 


\section{Discussion}

This study's main objective was to explore the influence of COVID-19 in the reintegration and readaptation process of a group a Spanish women returnee in the framework of female SIE returned to the Spanish context. Previous studies conducted in different geographical areas in Spain show that the integration process of highly educated migrant women from different nationalities is highly gendered and the intersection of gender, race, class and other determinants have an impact on migrant women's migratory careers development, their aspirations, expectations and migratory projects [1,67-69]. Such studies shed light on highly educated migrant women's vulnerabilities derived from macro, meso and micro determinants and the existence of phenomena such as overqualification, deskilling, reskilling, upskilling $[1,70,71]$ and identity transformation, which are mandatory in order to fit with the host society and local labour market. By comparing female and male migratory careers of highly skilled or highly educated professionals, scholars stressed the presence of gendered forms of socio-economic integration. On the one hand, a more lineal and coherent social and professional paths and integration related to the male migration are embedded in privileged processes determined by institutional criteria, addressed to the attraction of differentiated professionals organized in higher and privileged spheres of labour market (business, ICT, economic sectors). On the other hand, migrant women with higher or lower educational level in Spain have to overcome structural barriers. The findings raised other unsolved issues, confirming other studies' evidence about the issue of official recognition, assessment and evaluation of skills and education, which are different depending on the contexts and positionality of professionals, as they are socially constructed: this problematic is also shared with migrant women from different nationalities in Spain. Indeed, migrant and returned women's skills and/or job experience gained abroad often suffer from mismatch in the readaptation process [2]. Therefore, migrant women in the first step of integration opt for bridge works [1], or moonlighting situations, reskilling/upskilling strategies, addressed to shape non-lineal, precarious and interrupted migratory careers with high level of changes, bifurcations $[1,69,70]$. Thus, related to this evidence, my main hypothesis confirms the existence of similarities in the migratory careers of immigrant women from different nationalities and Spanish SIE women returnee in Spain, based on gendered socio-economic (re)integration processes. In detail, my findings confirm the hypothesis that the two mentioned groups have similar (re)integration and (re)adaptation processes consisted of vulnerabilities based on gendered processes, in particular liked to the dynamics raised from life-work imbalance, mono-parental families with caring problems, difficult maternity in challenging times, child and elderly caring, precarious jobs and salaries, in Spain.

In addition, my findings indicate that the articulation of macro, meso and micro dimensions is important in the analysis of human mobility. During the life course in space and time, SIE women returnees' migratory careers are articulated in relation to both external and internal factors [18]. Many of them are not under migrant people's control and COVID-19 is an added barrier for SIE women's relocation in the local labour market in the different local communities analysed in Spain. In that sense, as the principal motivation in SIE women was the professional advancement and career development once they come back to their home country, it should be stressed that, contrary to expectations, the experience they acquired abroad is not worth and suitable to the labour market needs and they are blocked in a job-educational mismatch, similar to migrant women from different nationalities settled in Spain [1,42]. Both migrant women and returnees' socio-occupational and economic situation worsened due to the COVID-19 pandemic; manifesting the problem of immobility in the development of their professional career paths, overqualification or underqualification are the common denominator in their experiences of return to the home country, as well as for migrant women in Spain [11]. Consequently, as Ortiga also claims [72], the precariousness of highly educated returnee women in the labour market of their home country is common, due to the volatile global labour market. Thus, orientation and counselling towards skill-building plans based on reskilling or upskilling for returnee 
people and women would be an added value for a sustainable reintegration plan. "Aspiring migrants who have invested in skill training in order to be transnationally mobile find themselves immobilised" [44] (p. 2246) by different demands of the local labour market in the country of emigration and mismatched in the return experience in their home county $[2,63]$. Related to this, the present study is aligned with the "Feminist Plan for Sustainability and Social Justice" [64] launched by UN Women, which aims to represent a roadmap for putting gender equality, social justice and sustainability as core questions in the context of recovery. In this context, countries have implemented different socioeconomic measures and actions for protecting migrant population. Finally, in the pandemic, migrant and Spanish SIE women returnee's professional trajectories have experienced an impasse in the development of personal aspirations and professional expectations. Nevertheless, agency and resilience seems to be the most popular strategies to move through the difficulties. Especially resilience is the best strategies at psychological level to overcome mental health problems due to the COVID-19 conditions and consequences, confirming Silvia Marcu's findings related to Romanian people in Spain [11].

This paper engaged with Objective 21: "Cooperate in facilitating safe and dignified return and readmission, as well as sustainable reintegration" (see [5]). The paper concludes that the COVID-19 response policies and return policies during the pandemic are limited or void, do not cover families' and women's needs in return strategy, increasing more and more the previous vulnerabilities of mobile women and creating a gap in the empowerment of women and girls, women and their children, involved in the negative conditions of return and post-COVID-19 response and recovery situation $[6,10,11,13,49,64]$ and there is no discrimination in terms of origin, gender, class, race, status, etc. On the contrary, the categories summarized could mean a scale of worsening of individuals' circumstances. Today's situation is a global challenge for a sustainable return option and opportunity within the framework of human mobility, especially from the intersectional perspective, which is focused on crossing gender with different socio-cultural categories [40].

"As expected, border closure announcements provoked desires to return to countries (...). In this context, it is important to note that research on population and development has proposed specific measures to provide assistance to citizens residing abroad in crisis situations. Hence, assistance to mobile citizens abroad should be a priority. The Spanish government, however, has had no strategy with specific measures to provide assistance to migrants and mobile citizens in the country before, during, and after the crisis phases in the country." [62] (p. 4-5).

Re-integration issues are gendered in Spanish SIE women returnee, as it is show in terms of maternity, life-work balance and burnout, found in the respondents' personal and professional trajectories. These findings confirm my principal hypothesis, and other studies based on migrant women's integration processes in Spain. Indeed, both migrant women and returnee women share the same dynamics in their personal and professional development paths, trying to achieve their socio-professional (re)integration process. It would be worth to investigate this phenomenon in other European country, as well as it would be interesting investigating the difference between men and women returnees to establish differentiation points and confirm more differentiation points based on gender.

Finally, from the most recent studies arose that the COVID-19 public health and social crisis has combined, globally, with previous existing crises of democratic stability and governance, spurring debate about the ability of developed democracies to respond effectively to emergencies confronting their citizens [73]. The crisis of COVID-19 has conducted governments, societies, communities and individuals towards "the disruptions and reconfigurations of gendered work and familial mobilities" [74]. Hence, in this new context the complex and multidimensional reintegration process, which includes the incorporation of intersecting categories in the analysis and the understanding of new (im)mobility dynamics of people and women on the move, urgently requires a holistic and needs-based approach and human-centered approach. This study confirms the view of international community on return shifting, which recognizes the centrality of the 
return to effective migration management with the return element, should also be included in discourses and policies (see [7]). At the same time, return should be included and recognized in the mobility management for countries of origin, transit and destination, in order to establish effective sustainability in the schemes of mobility, especially from a gender perspective; return policies and support measures should include better practices related to a successful application of family-work balance, with the main aim to mitigate the risks of isolation and mental illness, as well as the economic and socio-occupational risks linked to the worsening global and local situation arising from the pandemic.

\section{Conclusions}

The COVID-19 pandemic has worsened the situation of migrants, acting as the push factor both for a voluntary and forced decision-making process about the return to the home country in many cases analysed. Thus, COVID-19 has changed the patterns and behaviours of migrant people, in particular influencing the migratory careers of women in different ways and with different impacts, depending on macro-, meso- or micro-dimensional determinants. This paper analysed how the pandemic crisis has affected returnee women in Spain and how their return is linked to a sustainable mobility and to the structures of opportunities and constraints in the country of origin. Using ten life histories of highly educated returnee women, coming from the Latin American and Caribbean channels to Spain during and after the COVID-19 pandemic, and according to the Global Combat for Migration Goals for a sustainable and dignified return strategy to the home country and the Beijing Declaration, related to the gender perspective in public policies for returnees, the present paper highlights how despite the pandemic crisis, a sustainable approach can help to protect and promote better human mobility, confirming the findings highlighted by Silvia Marcu's work on the trajectories of the Romanian people in Spain (see [11] p. 15).

In this study I have identified a gap in migration studies on the return and reintegration process of highly educated migrant women to their country of origin, and in this specific case study to Spain. Thus, by identifying hindering and fostering factors in the migratory trajectories of respondents, in a relatively new process of return migration in the pandemic times, this study sheds light on the risk of chronicity related to the difficulties rose within the return migration, and the stagnation in the development of their professional careers, which is accentuated or extended in the case of single-parent families. Such a problematic situation raised questions and more uncertainty during and after the COVID-19 pandemic. This study has stressed relevant points which need to be investigated as they are critical points addressed to a better understand of the barriers linked to human mobility and sustainability, especially in the case of migrant women who returned to their country of origin, based on voluntary or non-voluntary decision- making processes.

To answer the research question, I stress that COVID-19 has had a negative impact on the returnee women and their families' processes, as well as on their children, especially for women in a single-parent family situation. Health and social crises, derived from COVID-19 lockdown and restrictive measures for protecting society from SARS-CoV-2, has had negative effects on returnee women's mental health and the balancing of their personal aspirations and professional expectations in Spain, confirming the evidence from IOM and UN studies and recent reports $[13,29,62]$. Moreover, findings confirm that lockdown and confinement reinforce isolation, as showed by the IOM previously, and that this situation has accelerated mental health problems. Moreover, migrants' return and reintegration take place in different ways, depending on the communities and countries of return, which often have not "the capacities to provide an environment conducive to sustainable reintegration due to a lack of local infrastructure and resources. Hence, reintegration assistance in countries of origin is essential to enhance migrant well-being upon return and is therefore a crucial component of IOM's approach to return" [75].

To this end, I propose to extend other economic measures to support families and women with children in their readaptation processes, in order to protect them from socioeconomic slumping. In addition, it would be suitable to create mental illness prevention and 
mitigation points or online resources promoted by local authorities, in order to drive more sustainable return strategies and dignified conditions in human mobility, especially for women and their children. Another solution I propose is linked to the socio-communitarian level. In this sense, communitarian and local solutions at neighbourhood level should help to reduce the stress caused by COVID-19 at macro and micro level. A systemic relational approach to return migration could help to mitigate the isolation of returnee women, their families and their children. Reintegration policies could be reinforced by local networks, conformed by different stakeholders, aimed at the reintegration of returning migrant people. In that sense, local government orientation systems are needed, as well as public or private associations and entities for job relocation, companies, local and communitarian associations, which could create consortia addressed to support the returnee migrant women in their socio-economic and professional reintegration and career-path development process in their local communities.

Moreover, I identified three main patterns, on the basis of which the strategies to approach the return migration and the reintegration and readaptation process are different. It can be stressed that the main difference between steady return (first pattern) and chaotic return (third pattern) is focused on the opportunities and constraints that women had to face in the country of origin. Sustainability in the case of chaotic return could be applied by using more organized and structured return schemes, in which assistance for voluntary return from the host country to the country of origin were offered by governments in order to guarantee a more sustainable reintegration. Thus, online services for consulting would be the best strategy and/or economic aid available to organize return. In relation to skills, these are the pillar in the reintegration process of highly educated women; therefore, the application of personalised strategies of reskilling and readapting professional profiles to the local labour market in the country of origin could allow for a transformation from a chaotic return (third pattern) to a steady return (first pattern) or more flexible return (second pattern). In contrast, flexible return is centred on the circulation of migrant people, based on the opportunities women find in other countries or in the home countries. This is based on a flexible human mobility, where macro, meso and micro determinants influence the challenges and the decision-making process of migrant women. Assistance in voluntary return should be applied and extended all over the world, in order to ensure migrant people in general and women in particular exercise substantive rights until the end of the pandemic period, as has happened in Italy, Slovenia, Norway and Switzerland, where individual assessment and applied procedures for voluntary return and reintegration support was carried out by governments in relation to the pandemic situation. Other countries have adopted reintegration counselling and other pre-existing departure services, or financial top-up was made available, as in the case of Germany, during the pandemic; services were also offered online, which is a good idea in order to make the chaotic return and reintegration process more steady or flexible, and thus more sustainable. Special attention should focus on women and migrants over 40 who want to return; economic aid and support would be a good strategy during the COVID-19 pandemic to increase resilience among the returnees.

In conclusion, in pandemic times return migration has increased and forced governments across the world to rethink the return of migrant people to their countries of origin. Thus, the pandemic has had a significant impact on migrant people generally and especially on migrant women's return processes and their life directions, trajectories, personal aspirations and professional and family projects and expectations. Restrictions and limitations in the form and processes of return should be studied better and in greater depth across the world, in order to understand the real impact of the pandemic on the lives of more vulnerable groups and their opportunities of reintegration. Therefore, this paper contributes to shedding light on some relevant gaps in the recent context of the pandemic, reinforcing the urgency for research to break down the barriers encountered by migrant women in their reintegration process during the return to their home countries. Related to this, and due to the little data available, I would stress the limitations of this 
research and the exploratory nature of the study, which have allowed me to articulate a typology useful for driving a reconceptualization of the relation between returnees, the COVID-19 pandemic and sustainability in the present-day situation of reassessment and reconsideration of return migration in a new and little explored context across the world. In that sense, and related to the sampling, on the one hand, it would be good to replicate this design in other countries, carrying out a comparison with other groups of women, from different origins and emigration trajectories, trying to compare the findings and the proposed typology about different return migration patterns, constructed from a gender perspective. On the other hand, it would be interesting to extend the study also to the migrant male returnee's trajectories, in order to understand the dynamics in the male universe at macro, meso and micro levels of analysis and explore the differences based on gender in the reintegration and readaptation process between women and men returned to Spain.

Funding: This research has received funding from the European Union's Horizon 2020 research and innovation programme under the Marie Skłodowska-Curie grant agreement $N^{\circ} 101027193$.

Institutional Review Board Statement: Not applicable.

Informed Consent Statement: Informed consent was obtained from all subjects involved in the study.

Data Availability Statement: Not applicable.

Conflicts of Interest: The author declares no conflict of interest.

\section{References}

1. Di Martino, M.L.; Maiztegui, C.; Aristegui, I. Balancing personal aspiration, family expectations and job matching: “Migratory career" reconstruction among highly educated women in the Basque Country. In Migration at Work: Aspirations, Imaginaries and Structures of Mobility, 1st ed.; Seiger, F.K., Timmerman, C., Salazar, N.B., Werts, J., Eds.; Leuven University Press: Leuven, Belgium, 2020; pp. 113-134. [CrossRef]

2. Di Martino, M.L. Emigración y Retorno desde una Perspectiva de Género. In Instrumentación Normativa de la Politica de Retorno de Emigrantes Españoles y la Atracción de Talento Global, 1st ed.; Fernández Avilés, J.A., García Valverde, M.D., Eds.; Tirant lo Blanch: Madrid, Spain; Volume 1, in press.

3. Dustmann, C. Return Migration: The European Experience. Econ. Policy 1996, 11, 213-250. [CrossRef]

4. De Haas, H. A theory of migration: The aspirations-capabilities framework. Comp. Migr. Stud. 2021, 9, 8. [CrossRef]

5. IOM. Global Combat for Migration (GCM). Available online: https:/ /www.iom.int/global-compact-migration (accessed on 21 June 2021).

6. Le Coz, C. Rewriting Migrant Returns and Reintegration after COVID-19 Shock Policy Brief. Available online: https://www. migrationpolicy.org/sites/default/files/publications/mpi-covid19-return-reintegration_final.pdf (accessed on 21 July 2021).

7. IOM. World Migration Report 2020. Available online: https://publications.iom.int/system/files/pdf/wmr_2020.pdf (accessed on 19 June 2021).

8. UN-DESA. International Migration Report 2019. Available online: https://www.un.org/en/desa (accessed on 7 July 2021).

9. Emakunde, Instituto Vasco de la Mujer. 2020. Available online: https://www.emakunde.euskadi.eus/informacion/covid-19 -igualdad-de-mujeres-y-hombres/u72-contema/es / (accessed on 23 July 2021).

10. UN. Policy Brief: The Impact of COVID-19 on Women. 2020. Available online: https:/ /www.un.org/sexualviolenceinconflict/ wp-content/uploads/2020/06/report/policy-brief-the-impact-of-covid-19-on-women/policy-brief-the-impact-of-covid-19 -on-women-en-1.pdf (accessed on 22 July 2021).

11. Marcu, S. Towards Sustainable Mobility? The Influence of the COVID-19 Pandemic on Romanian Mobile Citizens in Spain. Sustaibability 2021, 13, 4023. [CrossRef]

12. Molenaar, J. COVINFORM Project; University of Antwerp: Antwerp, Belgium. Available online: https://horizon-magazine.eu/ article/how-vulnerable-groups-were-left-behind-pandemic-response.html (accessed on 18 June 2021).

13. IOM. Cross-Border Human Mobility Amid and after COVID-19 Policy Paper. July 2020. Available online: https://www.iom.int/ sites/default/files/defaul/pp_cross-border_human_mobility_amid_and_after_covid-19_policy.pdf (accessed on 23 July 2021).

14. UN Women. Beijing Declaration and Platform for Action, Beijing +5 Political Declaration and Outcome. Available online: https://www.unwomen.org/en/digital-library/publications/2015/01/beijing-declaration (accessed on 2 July 2021).

15. Slade, B. Highly Skilled and Undertheorized: Women Migrant Professionals. In Calculated Kindness: Global Economic Restructuring and Canadian Immigration \& Settlement Policy; Folson, R.B., Ed.; Fernwood Publishing: Halifax, Nova Scotia, 2004 ; pp. $102-116$.

16. Spadavecchia, C.; Yu, J. Highly Skilled Migrants, Gender, and Well Being in the Eindhoven Region. An Intersectional Analysis. Adm. Sci. 2021, 11, 72. [CrossRef] 
17. Lewis, D. Using Life Histories in Social Policy Research: The Case of Third Sector/Public Sector Boundary Crossing. J. Soc. Policy 2008, 37, 559-578. [CrossRef]

18. Martiniello, M.; Rea, A. The concept of migratory careers: Elements for a new theoretical perspective of contemporary human mobility. Curr. Sociol. 2014, 62, 1079-1096. [CrossRef]

19. Instituto Nacional de Estadística (INE). Available online: https://www.ine.es/prensa/cp_j2020_p.pdf (accessed on 12 June 2021).

20. Hochschild, A.R. Global care chain and emotional surplus value. In On the Edge: Globalization and the New Millennium; Giddens, A., Hutton, W., Eds.; Sage Publishers: London, UK, 2000; pp. 130-146.

21. Baldassar, L.; Merla, L. Transnational Families, Migration, and Circulation of Care. Understanding Mobility and Absence in Family Life; Routledge: London, UK, 2014.

22. Encuesta Sobre la Situación Laboral de la Mujer Inmigrante en España. Análisis y Proposiciones para la Igualdad de Trato y la Lucha Contra la Discriminación. IOM-España and University of Comillas. 2015. Available online: https://www.comillas.edu/ images/OBIMID/Estudio_Sobre_la_Situaci\%C3\%B3n_Laboral_de_la_Mujer_Inmigrante._OIM_2015_1.pdf (accessed on 12 June 2021).

23. Donato, K.M.; Gabaccia, D. Gender and International Migration; Russell Sage Foundation: New York, NY, USA, 2015.

24. Walton-Roberts, M. Intermediaries and Transnational Regimes of Skill: Nursing Skills and Competencies in the Context of International Migration. J. Ethn. Migr. Stud. 2021, 47, 2323-2340. [CrossRef]

25. Rodríguez Puerta, R. Jóvenes Españoles Migrantes en Chile: Entre el crecimiento profesional y la ausencia de bienestar social. Cuad. Geogr. 2019, 59, 14-36. [CrossRef]

26. Economía de España. Available online: https://datosmacro.expansion.com/demografia/migracion/inmigracion/espana (accessed on 22 June 2021).

27. Instituto Nacional de Estadística (INE). Available online: https:/ / www.ine.es/jaxiT3/Datos.htm?t=24295\#!tabs-grafico (accessed on 18 June 2021).

28. ILO. Protecting Migrant Workers during the COVID-19 Pandemic. Recommendations for Policy-Makers and Constituents; Policy Brief; ILO: Geneva, Switzerland, 2020.

29. United Nations Network for Migration. Working Better Together. Policy Brief. The Global Compact for Migration (GCM): Well Governed Migration as an Essential Element of Effective COVID-19 Response. Available online: https://migrationnetwork.un. org/sites/default/files/docs/policy_brief-gcm_and_well_governed_migration_as_an_essential_element_of_effective_covid-19 _response_1.pdf (accessed on 22 June 2021).

30. Beaverstock, J.V. Transnational elites in the city: British highly-skilled inter-company transferees in New York city's financial district. J. Ethn. Migr. Stud. 2005, 31, 245-268. [CrossRef]

31. Scott, S. The Social Morphology of Skilled Migration: The Case of the British Middle Class in Paris. J. Ethn. Migr. Stud. 2006, 32, 1105-1129. [CrossRef]

32. Hercog, M.; Sandoz, L. Highly Skilled or Highly Wonted Migrants? Conceptualizations, Policy Designs, and Implementations of Highly-skilled Migration Policies. Migr. Lett. 2018, 15, 453-460. [CrossRef]

33. Birrell, B.; Hawthorne, L.; Richardson, S. Evaluation of the General Skilled Migration Categories Report; Department of Immigration and Citizanship: Canberra, Australia, 2006.

34. Boucher, A. How 'skill' definition affects the diversity of skilled immigration policies. J. Ethn. Migr. Stud. 2020, 46, 2533-2550. [CrossRef]

35. Al Ariss, A.; Crowley-Henry, M. Self-initiated expatriation and migration in the management literature: Present theorizations and future research directions. Car. Dev. Int. 2013, 18. [CrossRef]

36. Kunz, S. Priviledge mobilities: Locating the expatriates in migration scholarship. Geogr. Compass 2016, 10, 89-101. [CrossRef]

37. Petroff, A.; Alcalde, R.; Alarcón, A.; Cavalcanti, L. Las Migraciones Cualificadas desde una Perspectiva Teórica, 22nd ed.; Instituto Franklin-UAH: Alcalá de Henares, Spain, 2014. Available online: https://dev-if.singularlearning.com/sites/default/files/ proyectos/2021-04/Informe-USA.-N\%C2\%BA-22.pdf (accessed on 22 June 2021).

38. Batalova, J.; Lindsay Lowell, B. The best and the brightest: Immigrant professionals in the US. In The Human Face of Global Mobility: International Highly Skilled Migration in Europe, North America and the Asia-Pacific (Comparative Urban and Community Research); Smith, M.P., Favell, A., Eds.; Routledge: New York, NY, USA, 2006; pp. 81-102. [CrossRef]

39. Falcón, S.M. Transnational feminism and contextualized intersectionality at the 2001 world conference against racism. J. Women's Hist. 2012, 24, 99-120. [CrossRef]

40. Yuval-Davis, N. Situated intersectionality and social Inequality. Raisons Polit. 2015, 2, 91-100. [CrossRef]

41. Kofman, E. Gender and Skilled Migration in Europe. Cuad. Relac. Labor. 2012, 30, 63-89. [CrossRef]

42. Shershneva, J.; Fernández, I. Factores explicativos de la sobrecualificación de las mujeres inmigrantes: El caso vasco. Rev. Esp. Sociol. 2018, 27, 127-154. [CrossRef]

43. Hampson, I.; Junor, A. Stages of the Social Construction of Skill: Revisiting Debates over Service Skill Recognition; Wiley Online Library: Hoboken, NJ, USA, 2015.

44. Liu-Farrer, G.; Yeoh, S.B.; Baas, M. Social Construction of Skill: An analytical approach toward the question of skill in cross-border labour mobility. J. Ethn. Migr. Stud. 2020, 47, 2237-2251. [CrossRef]

45. Nowicka, M. Migrating skills, skilled migrants and migration skills: The influence of contexts on the validation of migrants' skills. Migr. Lett. 2014, 11, 171-186. [CrossRef] 
46. Yeoh, B.S.; Huang, S. Introduction: Fluidity and Friction in Talent Migration. J. Ethn. Migr. Stud. 2011, 37, 681-690. [CrossRef]

47. Liu-Farrer, G.; Shire, K. Who are the fittest? The question of skills in national employment systems in an age of global labour mobility. J. Ethn. Migr. Stud. 2021, 47, 2305-2322. [CrossRef]

48. UNHCR. Compilation of Statements by Human Rights Treaty Bodies in the Context of COVID-19. Public Document. 2020. Available online: https://www.ohchr.org/Documents/HRBodies/TB/COVID19/External_TB_statements_COVID-19_19jun2 0.pdf (accessed on 15 June 2021).

49. UNHCR. COVID-19 Does Not Discriminate; Nor Should Our Response. Available online: https://www.ohchr.org/EN/ NewsEvents / Pages/DisplayNews.aspx?NewsID=25730\&LangID=E (accessed on 21 June 2021).

50. González-Sánchez, G.; Olmo-Sánchez, M.I.; Maeso-González, E. Challenges and Strategies for Post-COVID-19 Gender Equity and Sustainable Mobility. Sustainability 2021, 13, 2510. [CrossRef]

51. Nguyen, M.H.; Armoogum, J. Perception and Preference for Home-Based Telework in the COVID-19 Era: A Gender-Based Analysis in Hanoi, Vietnam. Sustainability 2021, 13, 3179. [CrossRef]

52. Bronfman, N.C.; Repetto, P.B.; Cisternas, P.C.; Castañeda, J.V. Factors Influencing the Adoption of COVID-19 Preventive Behaviors in Chile. Sustainability 2021, 13, 5331. [CrossRef]

53. Campos, I. The COVID-19 Scenario in Terms of Gender: A Preliminary Analysis in IBEX-35 Companies. Sustainability 2021, 13, 5750. [CrossRef]

54. Khan, T.; Siriwardhane, P. Barriers to Career Progression in the Higher Education Sector: Perceptions of Australian Academics. Sustainability 2021, 13, 6255. [CrossRef]

55. Yueping, S.; Hantao, W.; Xiao-yuan, D.; Zhili, W. To Return or Stay? The Gendered Impact of the COVID-19 Pandemic on Migrant Workers in China. Fem. Econ. 2021, 27, 236-253. [CrossRef]

56. Collins, C.; Landivar, D.C.; Ruppanner, L.; Scarborough, W.J. COVID-19 and the Gender Gap in Work Hours. Gend. Work Organ. 2020, 28, 101-112. [CrossRef]

57. Priyadarshini, A.; Chaudhury, S. Borders of an Epidemic. COVID-19 and Migrant Workers; Samandar, R., Ed.; Mahanirban Calcutta Research Group, CRG Publications: Kolkata, India, 2020.

58. Plummer, K. Documents of Life. And Invitation to a Critical Humanism; Sage Publishers: London, UK, 2005.

59. Windzio, M.; de Valk, H.; Wingens, M.; Aybek, C. (Eds.) A Life-Course Perspective on Migration and Integration; Springer: Dordrecht, The Netherlands, 2011.

60. Schittenhelm, K. Overcoming barriers: Career trajectories of highly skilled members of the German second generation. In $A$ Life-Course Perspective on Migration and Integration; Wingens, M., Windzio, M., de Valk, H., Aybek, C., Eds.; Springer: Dordrecht, The Netherlands, 2011; pp. 101-120.

61. Thomas, D.R. A General Inductive Approach for Analyzing Qualitative Evaluation Data. Am. J. Eval. 2006, 27, 237-246. [CrossRef]

62. IOM. Towards an Integrated Approach to Reintegration in the Context of Return; IOM: Geneva, Switzerland, 2017.

63. Arowolo, O.O. Return Migration and the Problem of Reintegration; Blackwell Publisher Ltd.: Oxford, UK, 2000 ; Volume 38.

64. UN Women. Beyond COVID-19: The Feminist Plan for Sustainability and Social Justice. Available online: https://www. unwomen.org/en/digital-library/publications/2021/06/feminist-plan (accessed on 15 June 2021).

65. Hagan, J.; Lowe, N.; Quingla, C. Skills on the Move: Rethinking the Relationship between Human Capital and Immigrant Economic Mobility. Work Occup. 2011, 38, 149-178. [CrossRef]

66. Hagan, J.; Hernández-León, R.; Demonsant, J.-L. Skills of the "Unskilled": Work and Mobility among Mexican Migrants; University of California Press: Oakland, CA, USA, 2015.

67. Fernández, M.; Parra, M.C. Integration of Highly Skilled Third Country Nationals in Europe: A New Proposal for Circular Talent Management; Ed. Kadmos: Salamanca, Spain, 2013.

68. Roca, J. De sur a norte, de norte a sur: El balance laboral de mujeres cualificadas migrantes por amor. Rev. Andal. Antrop. 2016, 11, 92-120. [CrossRef]

69. Timmerman, C.; Martiniello, M.; Rea, M.; Wets, J. New Dynamics in Female Migration and Integration; Routledge: New York, NY, USA, 2015.

70. Liversage, A. Finding a path: Investigating the labour market trajectories of high-skilled immigrants in Denmark. J. Ethn. Migr. Stud. 2009, 35, 203-226. [CrossRef]

71. Kofman, E.; Raghuram, P. Gender and skilled migrant: Into and beyond the workplace. Geoforum 2004, 36, 149-154. [CrossRef]

72. Ortiga, Y.Y. Shifting employabilities: Skilling migrants in the nation of emigration. J. Ethn. Migr. Stud. 2021, 47, 2270-2287. [CrossRef]

73. Adey, P.; Hannam, K.; Sheller, M.; Tyfield, D. Pandemic (Im)mobilities. Mobilities 2021, 16, 1-19. [CrossRef]

74. Boucher, A.; Stears, M.; Hooijer, G.; King, D.; Napier, I. COVID-19: A Crisis of Borders. PS Political Sci. Politics 2021, 1-6. [CrossRef]

75. IOM. Enhancing Migrant Well-Being upon Return through an Integrated Approach to Reintegration. Global Combat Thematic Paper. 2017. Available online: https://www.iom.int/sites/default/files/our_work/ODG/GCM/IOM-Thematic-Paper-IntegratedApproach-to-Reintegration.pdf (accessed on 20 July 2021). 